\title{
The impact of early Holocene Arctic shelf flooding on climate in an atmosphere-ocean-sea-ice model
}

\author{
M. Blaschek and H. Renssen \\ Cluster Earth \& Climate, Faculty of Earth and Life Sciences, VU University Amsterdam, De Boelelaan 1085, 1081HV \\ Amsterdam, the Netherlands
}

Correspondence to: M. Blaschek (m.blaschek@vu.nl)

Received: 17 July 2013 - Published in Clim. Past Discuss.: 25 July 2013

Revised: 24 October 2013 - Accepted: 30 October 2013 - Published: 27 November 2013

\begin{abstract}
Glacial terminations are characterized by a strong rise in sea level related to melting ice sheets. This rise in sea level is not uniform all over the world, because regional effects (uplift and subsidence of coastal zones) are superimposed on global trends. During the early Holocene the Siberian Shelf became flooded before $7.5 \mathrm{ka} \mathrm{BP}$ and the coastline reached modern-day high stands at $5 \mathrm{kaBP}$. This area is currently known as a sea-ice production area and contributes significantly to the sea-ice exported from the Arctic through the Fram Strait. This leads to the following hypothesis: during times of rising sea levels, shelves become flooded, increasing sea-ice production on these shelves, increasing sea-ice volume and export through the Fram Strait and causing the sea-ice extent to advance in the Nordic Seas, yielding cooler and fresher sea surface conditions. We have tested this hypothesis in an atmosphere-ocean-sea-ice coupled model of intermediate complexity (LOVECLIM). Our experiment on early Holocene Siberian Shelf flooding shows that in our model sea-ice production in the Northern Hemisphere increases $(15 \%)$ and that sea-ice extent in the Northern Hemisphere increases (14\%) but sea-ice export decreases $(-15 \%)$ contrary to our hypothesis. The reason of this unexpected behaviour has its origin in a weakened polar vortex, induced by the land-ocean changes due to the shelf flooding, and a resulting decrease of zonality in the Nordic Seas pressure regime. Hence the winter Greenland high and the Icelandic low strengthen, yielding stronger winds on both sides of the Nordic Seas. Increased winds along the East Greenland Current support local sea-ice production and transport towards the South, resulting in a wider sea-ice cover and a southward shift of convection areas. The overall strength of the Atlantic meridional overturning circulation is reduced by
\end{abstract}

$4 \%$ and the heat transport in the Atlantic basin by $7 \%$, resulting in an annual cooling pattern over the Nordic Seas by up to $-4^{\circ} \mathrm{C}$. We find that the flooding of the Siberian shelf resulting from an orbitally induced warming and related glacioeustatic sea level rise causes a Nordic Seas cooling feedback opposed to this warming.

\section{Introduction}

The melting of land-based ice sheets during the last deglaciation (approximately 21 to $7 \mathrm{ka} \mathrm{BP}$ ) caused a prominent rise in global sea level of about $120 \mathrm{~m}$ (Siddall et al., 2003), with about half of this rise $(\sim 60 \mathrm{~m})$ taking place during the early Holocene (11.5 to $7 \mathrm{ka} \mathrm{BP}$ ). This rise in global sea level caused flooding of many exposed shelves around the world, although considerable regional differences in the timing of this shelf flooding existed due to the local uplift and subsidence of coastal zones (Lambeck and Chappell, 2001; Carlson and Clark, 2012), especially due to isostatic effects of the main ice sheets. This is especially important for the Arctic Ocean, where major shelves existed near these ice sheets, with some shelves actually being ice covered (e.g. Barents Shelf). Estimates for the Laptev Sea (i.e. a shelf not covered by ice sheets during the last glacial), illustrate the rapid rise in the sea level in the Arctic, from $31 \mathrm{~m}$ to $7 \mathrm{~m}$ below the present level between $8.9 \mathrm{ka}$ BP and $7.5 \mathrm{ka} \mathrm{BP}$ (Taldenkova et al., 2010; Bauch et al., 2001), leading to a completely flooded shelf at $5 \mathrm{ka} \mathrm{BP}$. A tentative extrapolation of these sea level stands to other shallow seas in the Arctic suggests that large areas were affected by similar flooding during the early Holocene, such as the large shelf areas in the East Siberian 

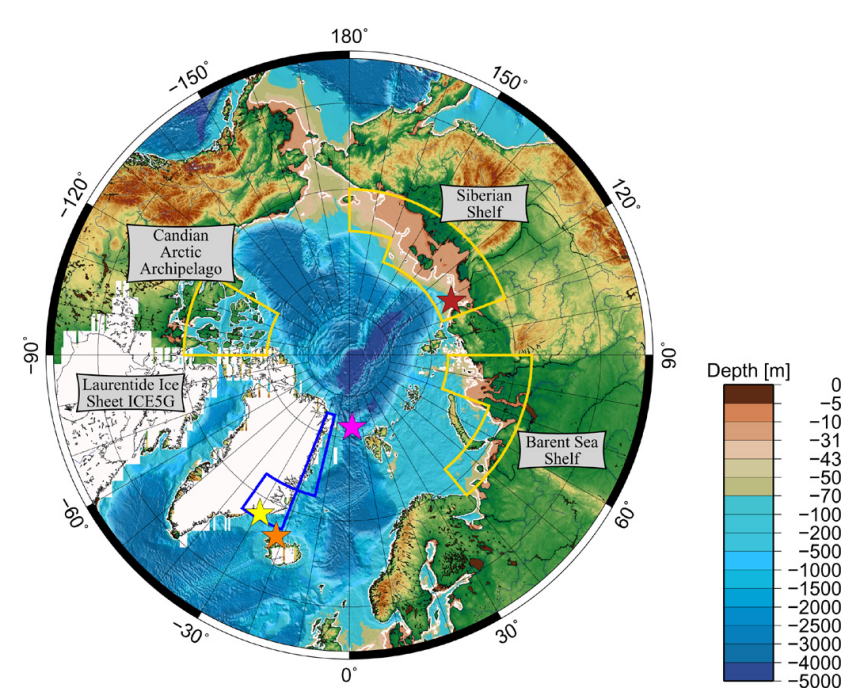

Fig. 1. Topographic map showing modern day bathymetry (National Geophysical Data Center, 2001) in the Arctic and $9 \mathrm{ka}$ BP ICE5G ice mask from Peltier (2004). Contour level -31 (white) is chosen to reflect lower sea-level stand for the Laptev Sea as reconstructed by Bauch et al. (2001) (their study area is indicated by a red star). Other stars show study locations referred to in the discussion: the orange star is the study area from Andrews et al. (2009), the purple star near the Fram Strait is from Müller et al. (2009) and the yellow star denotes the core location from Jennings et al. (2002). Yellow boxes indicate shelf areas and blue boxes indicate regions used in Fig. 5, north-western and south-western Nordic Seas.

Sea, the Kara Sea and parts of the Bering Sea (Fig. 1). This raises the question what the impact of such large scale flooding of shelves was on the climate during the early Holocene.

At present-day Arctic shelves are zones for numerous processes in the ocean, like ocean-atmosphere heat exchange, upper ocean stratification, deep-water formation and freshening of the upper ocean from river input. And most importantly, Arctic shelves are zones of sea-ice production. Sea-ice processes and feedbacks dominate the Arctic Ocean, the only polar ocean. Sea ice is formed all over the Arctic Ocean and sea-ice production rates are highly variable and location dependent (Tamura and Ohshima, 2011). Most literature divides sea-ice production into total and polynya-based sea-ice production. In a current study by Tamura and Ohshima (2011), 10 zones of considerable polynya-based sea-ice production are listed in the Arctic for present day. They find high ice production rates in the Canadian Archipelago $\left(842 \pm 243 \mathrm{~km}^{3} \mathrm{yr}^{-1}\right)$, the Northern Baffin Bay $\left(353 \pm 69 \mathrm{~km}^{3} \mathrm{yr}^{-1}, \mathrm{NBB}\right)$ and the Kara Sea $\left(342 \pm 71 \mathrm{~km}^{3} \mathrm{yr}^{-1}\right)$. The rates for the East Siberian Sea $\left(195 \pm 46 \mathrm{~km}^{3} \mathrm{yr}^{-1}\right)$ and the Laptev Sea $\left(152 \pm 43 \mathrm{~km}^{3} \mathrm{yr}^{-1}\right)$ are ranked 7 th and 9 th individually, but taken together they are similar to the rate for the Kara Sea. However, estimates for ice production rates vary substantially between different studies. For instance, estimates of the polynyabased sea-ice production in the Laptev Sea range from
$55 \mathrm{~km}^{3} \mathrm{yr}^{-1}$ (Willmes et al., 2011) to $258 \mathrm{~km}^{3} \mathrm{yr}^{-1}$ (Dethleff et al., 1998). In a similar way total sea-ice production in the Laptev Sea varies between $845 \mathrm{~km}^{3} \mathrm{yr}^{-1}$ (Zakharov, 1966) and $950 \pm 350 \mathrm{~km}^{3} \mathrm{yr}^{-1}$ (Dmitrenko et al., 2009). Despite the uncertainty in these estimates and therefore relative importance, a striking feature of most of these polynyabased production zones is that they are shelf regions. Polyak et al. (2010) summarize that for the present day most firstyear ice is formed over continental shelves. Another study by Dethleff and Kuhlmann (2010) connects deposited seaice rafted sediments near the Fram Strait to shelves in the Kara and Laptev Sea, indicating these regions as a major origin of Fram Strait sea-ice export. Just like Rigor and Colony (1997), who have identified that $20 \%$ of the sea ice leaving the Fram Strait originates in the Laptev Sea. The Transpolar Drift transports sea ice across the pole into the Nordic Seas passing through the Fram Strait. Transported along the East Greenland Current (EGC) southward, melting of the sea ice is subsequently expected to release relatively cool freshwater, cooling the upper ocean and reducing surface salinities in the Nordic Seas. To summarize, a dynamic link between Arctic shelves and sea-ice production is evident and its implications on Arctic sea-ice volume and extent are probably closely related to the climate in the Nordic Seas.

Bauch et al. (2001) have suggested that, in the early Holocene, the flooding of the Arctic shelves increased seaice production, impacting the transport and export of sea ice to the Nordic Seas. Recently Werner et al. (2013) suggested such a stepwise response of Fram Strait sea-ice conditions due to postglacial Siberian shelf flooding before $5 \mathrm{ka} \mathrm{BP}$. This leads to the following hypothesis: the flooding of the Arctic shelves resulted in a major increase in sea-ice production, leading to enhanced ice volume and export through the Fram Strait. Following this hypothesis, we expect that during times of lower sea levels (e.g. before the flooding at $7.5 \mathrm{ka} \mathrm{BP}$ ), the lower sea-ice cover was associated with relatively high sea surface temperatures (SSTs) and sea surface salinities (SSSs) along the EGC, compared to the case when the shelves are flooded (e.g. later in the Holocene). Thus, the shelf flooding is expected to have had a cooling influence in the Nordic Seas, implying that flooding of the Arctic shelves could have acted as a negative feedback, during a warming climate. This feedback might have been active during terminations when global climate is responding to an orbital-induced warming, leading to melting of land-based ice sheets and rising sea level. The shallow Arctic shelves facilitate sea-ice production compared to the deep Arctic Ocean and counteract high latitude warming, possibly reversing the long-term warming trend and resulting in a cold reversal. Important for the severity of the impact on climate seems to be the speed of this transgression.

The dynamic relationship between sea-ice production and dry shelves can be tested with an ocean-atmosphere coupled climate model to evaluate the significance of such changes on past climates. Previous modelling studies focusing on the last 
deglaciation have either kept the land-sea mask fixed (e.g. Roche et al., 2007; Friedrich et al., 2010; Roche et al., 2012) or have not specifically analysed the impact of the changes in land-sea distribution (Singarayer and Valdes, 2010). Thus, to our knowledge the impact of shelf flooding has not yet been addressed in modelling studies.

Our aim in this study is to address changes induced by Arctic shelf flooding with the help of LOVECLIM, a fully coupled climate model of intermediate complexity (Goosse et al., 2010). We designed simulations for the early Holocene with and without dry shelves. From previous studies of the early Holocene, the Laurentide ice sheet (LIS, e.g. Renssen et al., 2009) and the Greenland ice sheet (GIS, e.g. Blaschek and Renssen, 2013) have been recognized as important factors in the Nordic Seas climate. Together with the downwind cooling effect of the LIS and its melt water and additional melt water from the GIS, sea-ice conditions are considerably altered and sea-ice production is facilitated by atmospheric cooling and shutdown of local convection. Therefore, we extend on the study of Blaschek and Renssen (2013) and include an analysis of simulations for the early Holocene including both LIS and GIS forcings together with and without flooded Arctic shelves.

\section{Methods}

\subsection{The LOVECLIM model}

We extend the modelling approach applied by (Blaschek and Renssen, 2013), using the same Earth system Model of Intermediate Complexity (EMIC) LOVECLIM (version 1.2; Goosse et al., 2010) for our experiments. The model includes a representation of the atmosphere, the ocean and sea ice, the land-surface and its vegetation. The components not activated in our LOVECLIM version are the dynamical ice sheet model and the carbon cycle model. As a detailed description of the model can be found in Goosse et al. (2010), we only provide a brief summary and highlight relevant features. The ocean-sea ice component is CLIO3 (Goosse and Fichefet, 1999), a ocean general circulation model with a horizontal resolution of $3^{\circ} \times 3^{\circ}$ latitude-longitude and 20 vertical levels, coupled to a three-layer dynamic-thermodynamic sea ice model (Fichefet and Maqueda, 1997, 1999) with an advanced scheme to determine the sea-ice edge more precisely in a coarse resolution model as explained by Goosse et al. (2010). For present-day it simulates a reasonably well Arctic sea-ice distribution, although the magnitude of the seasonal cycle is too weak (Goosse et al., 2007; Goosse et al., 2010). Mass exchanges between the ocean and sea ice are treated as negative and positive salt fluxes, implying that ice-related freshwater fluxes are virtual salt fluxes. As detailed by Goosse et al. (2010), this is a simplification that originates in CLIO's free-surface. The ocean bathymetry and the land-sea mask are derived from modern observations and reduced to the lower resolution of our model. To mimic dry shelves in the model, we converted ocean cells in selected shelf areas from vertical level 4 ( -38 to $-45 \mathrm{~m}$ depth) upwards to land cells, consistent with sea level estimates of Bauch et al. (2001) for $8.9 \mathrm{ka} \mathrm{BP}$ of $-31 \mathrm{~m}$. As the coupling between ocean and atmosphere depends thoroughly on the land-sea mask, we had to recalculate coupling parameters to account for the changes in the prescribed land-sea distribution.

The atmospheric model is called ECBILT (Opsteegh et al., 1998) a spectral T21 three-level quasi-geostrophic model with a built-in bucket-type hydrological model for soil moisture and runoff. Cloud cover is climatologically prescribed. The vegetation is handled by VECODE (Brovkin et al., 2002), a dynamical vegetation model simulating two plant functional types (trees and grasses), and desert as a dummy type. As in Blaschek and Renssen (2013), the extent and elevation of ice sheets are manually prescribed and consistent with sea level as in Peltier's (2004) ICE-5G model. The climate sensitivity of LOVECLIM (version 1.2) to a doubling of the atmospheric $\mathrm{CO}_{2}$ concentration is at the lower end of the range found in global climate models $(1.9 \mathrm{~K}$ after $1000 \mathrm{yr}$; Goosse et al., 2010). Deep convection takes place in both the Nordic Seas and the Labrador Sea (Goosse et al., 2010) and the simulated characteristics of the deep ocean circulation compare reasonably well with other model results (e.g. Weaver et al., 2012). The model has been used successfully in numerous palaeoclimatological modelling studies for example in Wiersma and Renssen (2006) investigating the $8.2 \mathrm{ka}$ BP event or by Renssen et al. $(2009,2010,2012)$ in studies of the Holocene Thermal Maximum.

\subsection{Experimental design}

In this study we use the experiments $9 \mathrm{kOG}$ and 9kOGGIS from Blaschek and Renssen (2013) and an additional five quasi-equilibrium snapshot experiments with fixed forcings at $9 \mathrm{kaBP}$ and one with fixed pre-industrial forcings. In all experiments, orbital parameters and greenhouse-gas concentrations are taken from the PMIP3 protocol (http://pmip3. lsce.ipsl.fr/). Our snapshot experiments have been run for 500 model years, and the analysis is based on the last $100 \mathrm{yr}$ of each simulation. Key features about our experimental setup are summarized in Table 1.

We use the same control snapshot experiment for $9 \mathrm{ka} \mathrm{BP}$ background conditions with orbital and greenhouse-gas forcing (9kOG) and an experiment that includes the impacts of LIS and GIS (9kOGGIS) as in Blaschek and Renssen (2013). In order to test our hypothesis, we designed five experiments to affect sea-ice production zones relevant in our model, mimicking dry shelf areas. In all our simulations the Bering Strait remains open, consistent with palaeoceanographic evidence indicating that this strait already became active again at $11.1 \mathrm{ka} \mathrm{BP}$ when sea level was $50 \mathrm{~m}$ below the current level (Elias et al., 1996). The "new" land cells at the shelves are 
Table 1. Summary of experiments. Shelf areas according to Fig. 1.

\begin{tabular}{|c|c|c|c|}
\hline Experiment name & & Initial conditions & Changes \\
\hline $0 \mathrm{kOG}$ & & Orbital (0 BP), Greenhouse Gases (1750 AD) & no \\
\hline $9 \mathrm{kOG}$ & & Orbital (9 ka BP), Greenhouse Gases (9 ka BP) & no \\
\hline 9kOGBAR & $9 \mathrm{kOG}+$ & Dry Barent Sea Shelf & Land-Sea mask + Bathymetry \\
\hline 9kOGCAN & $9 \mathrm{kOG}+$ & Dry Canadian Arctic Archipelago Shelf & Land-Sea mask + Bathymetry \\
\hline 9kOGSIB & $9 \mathrm{kOG}+$ & Dry Siberian Shelf & Land-Sea mask + Bathymetry \\
\hline 9kOGSHELF & $9 \mathrm{kOG}+$ & Dry Arctic Shelves & Land-Sea mask + Bathymetry \\
\hline \multicolumn{4}{|c|}{ Additional experiments } \\
\hline 9kOGGIS & $9 \mathrm{kOG}+$ & $\begin{array}{l}\text { Laurentide ice sheet (LIS, remnant ice sheet } \\
+ \text { Melt water }(0.09 \mathrm{~Sv}))+ \text { Greenland ice } \\
\text { sheet (GIS) melt water }(13 \mathrm{mSv})\end{array}$ & Topography, Melt water \\
\hline 9kOGSIBGIS & 9kOGGIS + & Dry Siberian Shelf & $\begin{array}{l}\text { Land-Sea mask }+ \\
\text { Bathymetry, Topography, } \\
\text { Melt water }\end{array}$ \\
\hline PRE2005 & \multicolumn{2}{|c|}{ Transient simulation including orbital and greenhouse gases from 1765 to 2005} & no \\
\hline
\end{tabular}

set to behave like adjacent land cells with seasonal changes in albedo and vegetation.

In the five additional experiments, we prescribed different combinations of land-sea masks in the Arctic region, which correspond in each experiment to a different land area added, to represent a specific dry shelf area. These simulations are named 9kOGBAR, 9kOGCAN, 9kOGSIB, 9kOGSHELF and 9kOGSIBGIS. In 9kOGBAR changes in the land-sea mask in the bigger Kara and Barents sea area (cf. Fig. 1, Barents Sea Shelf) result in five ocean cells becoming land and four being lowered. In 9kOGCAN the existing shelf region in the Canadian Arctic Archipelago (CAA) is removed and four ocean cells are converted to land (cf. Fig. 1, CAA). In 9kOGSIB the new land-sea mask for the East Siberian Shelf (cf. Fig. 1) converts 10 coastal ocean cells to land and lowers two surrounding ocean cells. Simulation 9kOGSHELF combines the impact of the three shelf areas (9kOGBAR, 9kOGCAN, 9kOGSIB). Coming from the glacial, shelf areas in the Barents Sea and the CAA are likely to be subject to subsidence from the Barents and Laurentide ice sheets, respectively (Bauch et al., 2001; Svendsen et al., 2004), lowering the relevance of our 9kOGBAR, 9kOGCAN and 9kOGSHELF simulation. From surface altitude differences between 9 and $0 \mathrm{ka}$ BP derived from Peltier's (2004) ICE-5G model, it can be inferred that the Barents Sea and the CAA were already flooded at $9 \mathrm{ka} \mathrm{BP}$. Therefore simulations 9kOGBAR and 9kOGCAN should be considered as sensitivity experiments, and are only used for evaluating the impact on sea-ice production in our model. Likewise, experiment 9kOGSHELF overestimates the total exposed Arctic shelf area at $9 \mathrm{kaBP}$, and should thus be interpreted as a maximum impact simulation. For the early Holocene it has been shown that during the Holocene Thermal Maximum (HTM) the Laurentide ice sheet (LIS) (cf. Fig. 1, Renssen et al., 2009) and the Greenland ice sheet (GIS) (Blaschek and Renssen, 2013) had a significant impact on the climate, especially on sea ice and convection depth in the Nordic Seas. These important climate features are relevant for the early Holocene climate but not necessarily for our hypothesis to test, but in order to have a complete overview of the response to the combination of all forcings, we also simulated the impact of the Siberian shelf on the early Holocene background climate affected by the LIS (melt flux to the St. Lawrence outlet $(50 \mathrm{mSv})$ and Hudson Bay $(40 \mathrm{mSv})$, as well as the remnant ice sheet as in Renssen et al., 2009) and melt water from the GIS (13 mSv) (Blaschek and Renssen, 2013) in simulation 9kOGSIBGIS. A comparison between 9kOGGIS (Blaschek and Renssen, 2013) and 9kOGSIBGIS therefore provides an idea of the relative importance of shelf flooding compared to all other forcings, including additional ice sheet topography, albedo and background melt fluxes, whereas a comparison of 9kOG and 9kOGSIB shows the effects of shelf flooding without this influence of the ice sheets.

To compare observed sea-ice volumes (Fig. 2), we also performed a transient simulation (PRE2005) that follows the Representative Concentration Pathways (RCP) (Meinshausen et al., 2011) greenhouse-gas concentrations from 1765 to 2005 AD.

\section{Results}

In order to test our hypothesis, we conducted experiments with different dry shelves to estimate the impact of these changes to the climate and the sea-ice conditions. We will first discuss the performance of our model for the present climate (Sect. 3.1.1), then analyse the impacts of the flooding of these shelf areas on sea-ice production and volume 


\section{Daily Arctic Sea Ice Volume}

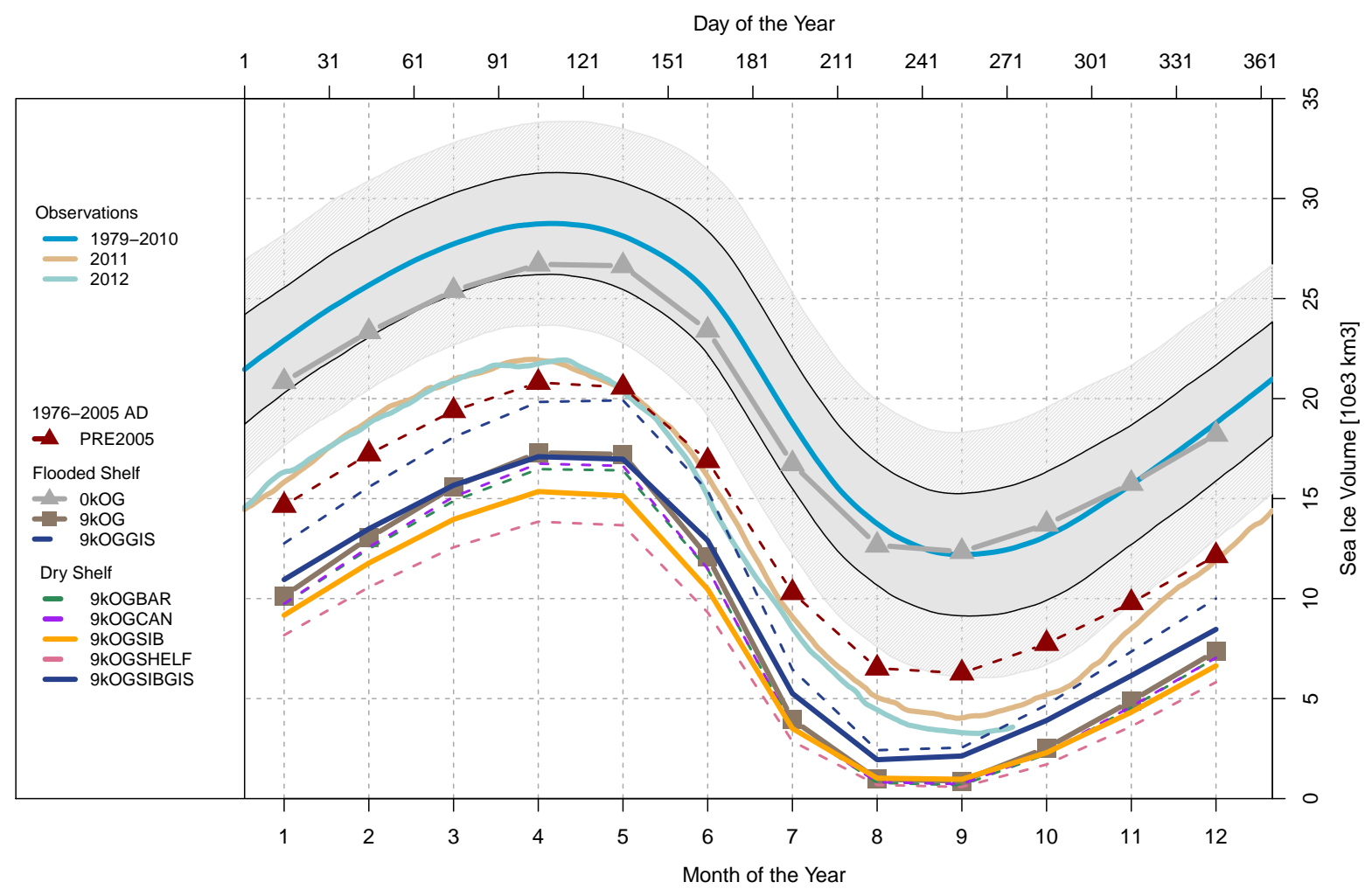

Fig. 2. Daily Arctic sea-ice volume from PIOMAS (Zhang and Rothrock, 2003) and monthly means for model experiments at 9 ka BP and $0 \mathrm{kaBP}$. Separated lines for most recent years 2011 and 2012. Grey areas denote one (two) standard deviations from 1979 to 2010 climatological mean. Please notice that LOVECLIM uses a fixed calendar with 360 days and the data embodies leap years. Model values are monthly means of the last $100 \mathrm{yr}$ of each simulation, except for simulation PRE2005 giving monthly means of the period 1976 to 2005 AD.

(Sect. 3.1.2) and proceed with impacts on the Nordic Seas (Sect. 3.2) and Northern Hemisphere (Sect. 3.3).

\subsection{Impact on Arctic sea-ice}

\subsubsection{Modern climate}

Our model simulates the modern seasonal cycle of Arctic sea-ice volume reasonably well, as is shown by a direct comparison with observations (Zhang and Rothrock, 2003, Fig. 2). The simulated seasonal cycle in sea-ice volume in our pre-industrial experiment $0 \mathrm{kOG}$ is very close to the observed mean for 1979-2010. However, our recentpast simulation (PRE2005) underestimates sea-ice volumes compared to these mean observations by $7.12 \times 10^{3} \mathrm{~km}^{3}$ $(\sim 34 \%)$, with values that are closer to recent sea-ice minima observed in 2011 and 2012. A major difference between PRE2005 and 0kOG is the radiative forcing (approx. $2 \mathrm{~W} \mathrm{~m}^{-2}$ globally higher for 1976 to 2005 as compared to 1750) due to greenhouse-gas concentrations. Goosse et al. (2007) found for LOVECLIM that the simulated sea-ice area fits reasonably well with modern-day observations. Our results confirm this, as we find that the simu- lated annual sea-ice area in our PRE2005 and 0kOG simulations $\left(9.6 \times 10^{12} \mathrm{~km}^{2}\right.$ and $10.6 \times 10^{12} \mathrm{~km}^{2}$, respectively) agree well with observations $\left(10.6 \times 10^{12} \mathrm{~km}^{2}\right.$, cf. Table 2). However observed Fram Strait sea-ice export shows considerable lower $\left(2.6 \times 10^{3} \mathrm{~km}^{3}\right.$, Spreen et al., 2009) volumes compared to $10.6 \times 10^{3} \mathrm{~km}^{3}$ of annual cumulative sea-ice export in our model. Consequently, the export of sea ice through the Fram Strait is likely to be too large in our model. The distribution of sea-ice production in the model is different from observations, because in our model the transpolar drift transports sea-ice from the western to the eastern side of the Arctic (Goosse et al., 2001; cf. Fig. 8, 9kOG, distribution is similar to present-day). This model bias results from the low resolution of the atmospheric component (Goosse et al., 2003; Goosse and Renssen, 2001), although Goosse et al. (2001) found that the atmospheric circulation in the Arctic and the position of Icelandic and Aleutian low is relatively close to observed ones under present-day conditions. The opposite wind direction is a result of an overestimation of the Aleutian low. Despite this deficiency we conclude that our model is able to produce sea-ice quantities at larger scale in a reasonable range at pre-industrial, suggesting that our model 
Table 2. Summary of annual mean and standard deviation of sea-ice parameters in nine different model simulations. Northern Hemisphere sea-ice volume in $\mathrm{km}^{3}$. Northern Hemisphere and Arctic annual cumulative sea-ice production $\left(0-360^{\circ} \mathrm{E}\right.$ and $40-90^{\circ} \mathrm{N}, 20-280^{\circ} \mathrm{E}$ and $65-$ $90^{\circ} \mathrm{N}$ ) in $\mathrm{km}^{3}$. Northern Hemisphere annual mean sea-ice area in $10^{12} \mathrm{~km}^{2}$. Annual cumulative Fram Strait sea-ice export in $\mathrm{km}^{3}$. Meridional overturning strength in the North Atlantic (AMOC) at $27^{\circ} \mathrm{N}$ in Sv. All values are calculated from the last $100 \mathrm{yr}$ of the simulations except for PRE2005 over 1976 to 2005 as Fig. 2. The corresponding data source for Northern Hemisphere sea-ice volume is the PIOMAS data from Zhang and Rothrock (2003). For Northern Hemisphere annual cumulative sea-ice production there are two estimates, the first one derived from Zhang and Rothrock (2003) and the second one from Tamura and Ohshima (2011), the latter denoting only polynya-based sea-ice production. Northern Hemisphere sea-ice area is taken from HadISST data (Rayner et al., 2003). Fram Strait sea-ice export estimates are taken from Spreen et al. (2009) (1st) and Kwok et al. (2004) (2nd). Recent estimates of the AMOC strength have been published by Kanzow et al. (2010).

\begin{tabular}{|c|c|c|c|c|}
\hline & \multirow{4}{*}{$\begin{array}{l}\text { Experiments } \\
\text { Observations } \\
\text { (mul. Sources) }\end{array}$} & \multicolumn{3}{|c|}{ Sea ice $\left[10^{3} \mathrm{~km}^{3}\right]$} \\
\hline & & Annual volume & \multicolumn{2}{|c|}{ Annual cumulative production } \\
\hline & & \multicolumn{2}{|c|}{ Northern Hemisphere } & Arctic \\
\hline & & $\begin{array}{r}20.66 \pm 6.72 \\
-\end{array}$ & $\begin{array}{r}16.08 \pm 6.18 \\
2.94 \pm 0.37\end{array}$ & - \\
\hline $\begin{array}{l}\text { Flooded } \\
\text { shelves }\end{array}$ & $\begin{array}{l}\text { PRE2005 } \\
\text { 0kOG } \\
9 \mathrm{kOG}\end{array}$ & $\begin{array}{r}13.54 \pm 5.40 \\
19.65 \pm 5.49 \\
8.83 \pm 5.99\end{array}$ & $\begin{array}{l}13.89 \pm 5.19 \\
13.54 \pm 5.11 \\
16.09 \pm 6.10\end{array}$ & $\begin{array}{l}11.76 \pm 4.27 \\
11.16 \pm 4.07 \\
13.81 \pm 5.08\end{array}$ \\
\hline $\begin{array}{l}\text { Dry } \\
\text { shelves }\end{array}$ & $\begin{array}{l}\text { 9kOGBAR } \\
\text { 9kOGCAN } \\
\text { 9kOGSIB } \\
\text { 9kOGSHELF }\end{array}$ & $\begin{array}{l}8.36 \pm 5.77 \\
8.44 \pm 5.84 \\
7.88 \pm 5.29 \\
6.95 \pm 4.88\end{array}$ & $\begin{array}{l}15.48 \pm 5.88 \\
15.73 \pm 5.97 \\
13.99 \pm 5.33 \\
12.89 \pm 4.93\end{array}$ & $\begin{array}{l}13.29 \pm 4.88 \\
13.46 \pm 4.94 \\
11.90 \pm 4.41 \\
10.99 \pm 4.08\end{array}$ \\
\hline $\begin{array}{l}\text { Flooded } \\
\text { Dry }\end{array}$ & $\begin{array}{l}\text { 9kOGGIS } \\
\text { 9kOGSIBGIS }\end{array}$ & $\begin{array}{r}11.37 \pm 6.32 \\
9.58 \pm 5.48\end{array}$ & $\begin{array}{l}17.25 \pm 6.41 \\
14.88 \pm 5.55\end{array}$ & $\begin{array}{l}14.23 \pm 5.12 \\
12.35 \pm 4.46\end{array}$ \\
\hline & & $\begin{array}{l}\text { Annual sea-ice } \\
\text { area }\left[10^{12} \mathrm{~km}^{2}\right]\end{array}$ & $\begin{array}{l}\text { Annual cumul. } \\
\text { Fram Strait sea-ice } \\
\text { export }\left[10^{3} \mathrm{~km}^{3}\right]\end{array}$ & $\begin{array}{lr}\text { Atlantic } & \text { Meridional } \\
\text { Overturning } & \text { Stream- } \\
\text { function }[\mathrm{Sv}] & \end{array}$ \\
\hline & $\begin{array}{l}\text { Observations } \\
\text { (mul. Sources) }\end{array}$ & $10.58 \pm 3.16$ & $\begin{array}{l}1.54 \pm 0.18 \\
2.22 \pm 0.50\end{array}$ & $18.70 \pm 2.10$ \\
\hline $\begin{array}{l}\text { Flooded } \\
\text { shelves }\end{array}$ & $\begin{array}{l}\text { PRE2005 } \\
0 \mathrm{kOG} \\
9 \mathrm{kOG}\end{array}$ & $\begin{array}{r}9.64 \pm 3.67 \\
10.65 \pm 3.08 \\
8.82 \pm 4.65\end{array}$ & $\begin{array}{r}7.07 \pm 1.88 \\
10.64 \pm 3.33 \\
6.36 \pm 1.89\end{array}$ & $\begin{array}{l}14.32 \pm 2.28 \\
15.27 \pm 2.18 \\
13.93 \pm 2.31\end{array}$ \\
\hline $\begin{array}{l}\text { Dry } \\
\text { shelves }\end{array}$ & $\begin{array}{l}\text { 9kOGBAR } \\
\text { 9kOGCAN } \\
\text { 9kOGSIB } \\
\text { 9kOGSHELF }\end{array}$ & $\begin{array}{l}8.44 \pm 4.50 \\
8.51 \pm 4.60 \\
7.74 \pm 4.15 \\
7.00 \pm 3.90\end{array}$ & $\begin{array}{l}6.30 \pm 2.07 \\
6.58 \pm 1.95 \\
7.49 \pm 1.92 \\
6.55 \pm 1.77\end{array}$ & $\begin{array}{l}13.68 \pm 2.42 \\
13.26 \pm 2.37 \\
14.54 \pm 2.39 \\
14.54 \pm 2.40\end{array}$ \\
\hline $\begin{array}{l}\text { Flooded } \\
\text { Dry }\end{array}$ & $\begin{array}{l}\text { 9kOGGIS } \\
\text { 9kOGSIBGIS }\end{array}$ & $\begin{array}{r}10.40 \pm 4.44 \\
9.02 \pm 4.12\end{array}$ & $\begin{array}{l}7.06 \pm 2.14 \\
7.56 \pm 2.23\end{array}$ & $\begin{aligned} 9.47 & \pm 2.50 \\
10.59 & \pm 2.43\end{aligned}$ \\
\hline
\end{tabular}

is suitable for a study of the impact of early Holocene shelf flooding on sea ice (cf. Fig. 2).

\subsubsection{Early Holocene}

Comparison of our orbital and greenhouse-gas simulations for $9 \mathrm{k}$ and $0 \mathrm{k} \mathrm{BP}(9 \mathrm{kOG}$ and $0 \mathrm{kOG}$, respectively), reveals that annual cumulative Arctic sea-ice production was higher $(+24 \%)$ in the experiment with early Holocene forcings (Table 2), while the values for both sea-ice area and volume are reduced for $9 \mathrm{ka} \mathrm{BP}$. This counter-intuitive result can be ex- plained by insolation differences of the early Holocene compared to present day. Associated with orbitally forced insolation anomalies $\left(-15 \mathrm{~W} \mathrm{~m}^{-2}\right.$ in October), the early Holocene had a bigger seasonal contrast than today, allowing more sea ice to grow during the winter half year, but decay faster in summer. Thus, the reduced annual mean sea-ice area and volume reflect the response to summer conditions, while the enhanced annual sea-ice production reflects the impact of reduced insolation in the winter half year.

As expected, flooding of the Arctic shelves results in an increase in simulated Arctic sea-ice production, as is clearly 
9 ka BP Simulation comparison

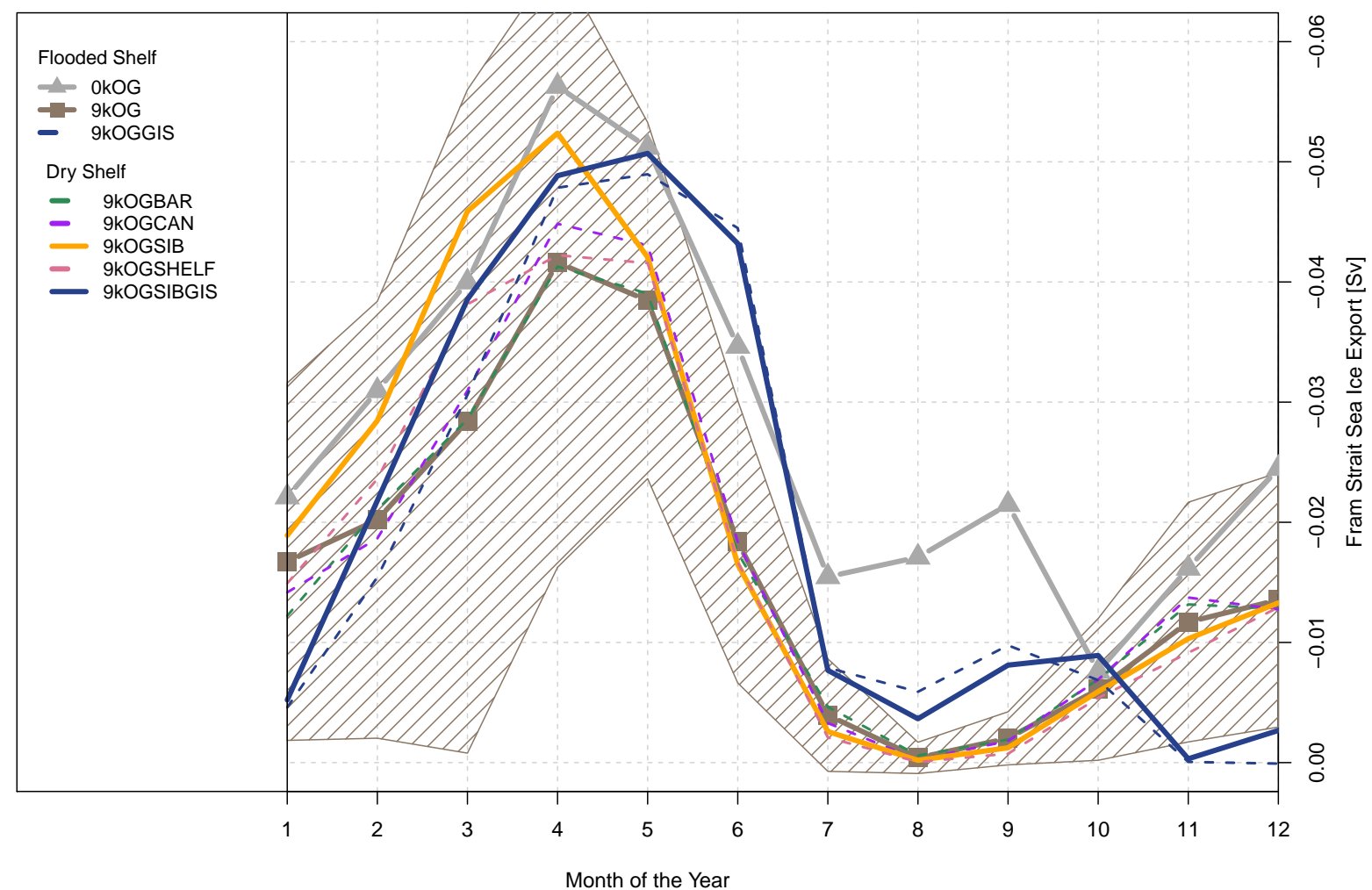

Fig. 3. Monthly mean Fram Strait sea-ice export for different simulations in Sv of the last $100 \mathrm{yr}$. The more negative the values are the more southward transport occurs. In the literature values are normally given as yearly exports, resulting from a sum of monthly values (cf. Table 2). Shaded area gives an estimation of the standard deviation of the monthly means for simulation 9kOG.

shown by the comparison of $9 \mathrm{kOG}$ with the experiments with dry shelves. For the Siberian shelf this increase due to flooding is $16 \%$ (i.e. $9 \mathrm{kOG} 13.8 \times 10^{3} \mathrm{~km}^{3}$ compared to 9kOGSIB $11.9 \times 10^{3} \mathrm{~km}^{3}$ ), accompanied by an increase of $12 \%$ in sea-ice volume over the whole Northern Hemisphere (Table 2). However, this difference in volume is mainly related to changes in winter, as in summer (August-September) our model simulates an almost ice-free Arctic Ocean for $9 \mathrm{kOG}$ and any other shelf experiment (cf. Fig. 2). Impacts of shelf flooding on sea-ice production, sea-ice volume and sea-ice area are in the range of 2 to $5 \%$ for simulations 9kOGBAR and 9kOGCAN compared to 9kOG. This is quite surprising as the associated shelves are categorized as high production areas by Tamura and Ohshima (2011) and one would expect a greater impact from these shelf areas, meaning that sea-ice production is obviously very robust there. The potential total impact of Arctic shelf flooding, as indicated by the difference between $9 \mathrm{kOG}$ and 9kOGSHELF, is a strong increase in sea-ice production $(+25 \%)$, and seaice volume $(+27 \%)$. When the impact of the remnant ice sheets is taken into account (i.e. by comparing 9kOGGIS and 9kOGSIBGIS), the impact of the flooding of the Siberian shelf on sea-ice production $(+15 \%)$ is similar to the results without this ice sheet effect $(+16 \%)$.

\subsection{Impacts on Nordic Seas}

The flooding of the Arctic shelves and the combined increase in sea-ice production have an indirect impact on the Nordic Seas via the export of sea ice through the Fram Strait. Despite the increase in sea-ice volume and area due to shelf flooding, the export of Arctic sea ice through the Fram Strait into the Nordic Seas (Fig. 3) decreased in simulation 9kOG from January to May relative to 9kOGSIB and shows a maximum of $41 \mathrm{mSv}\left(1293 \mathrm{~km}^{3} \mathrm{yr}^{-1}\right)$ in April compared to $52 \mathrm{mSv}$ in $9 \mathrm{kOGSIB}$. However, the reduced mean values are not significantly different for those months given the large interannual variability in these exports. This seasonal response is much weaker in the results showing the impact of flooding of the shelves in CAA and the Barents Sea on the Fram Strait sea-ice export. This indicates that the discussed response in sea-ice export, with a reduction from January to May, is mainly connected to flooding of the Siberian shelf. This reduction in Fram Strait sea-ice export due to shelf flooding is in contradiction with our hypothesis and counter-intuitive, 
raising the following question: what caused this response? The first step in explaining this response is to take a closer look at the changes induced in the Nordic Seas, followed by an analysis of polar atmospheric circulation changes and finally Arctic sea-ice transport.

The discussed expansion of Northern Hemisphere sea-ice cover in 9kOG causes the sea-ice edge along the EGC to advance, leading to a southward shift of local deep convection from $70^{\circ} \mathrm{N}$ in 9kOGSIB (Fig. 4b) to the southern tip of Greenland at $63^{\circ} \mathrm{N}$ (Fig. 4a). These changes in deep convection also affect the overall Atlantic meridional overturning circulation (AMOC), decreasing its strength by $4 \%$, from $14.5 \mathrm{~Sv}$ in $9 \mathrm{kOGSIB}$ to $13.9 \mathrm{~Sv}$ in $9 \mathrm{kOG}$. The southward shift of convection results in cooler and fresher surface waters near the Denmark Strait (Fig. 5d-f) and along the east coast of Greenland as far north as the Fram Strait (Fig. 5a-c). The southward expansion of sea ice along the EGC increases seaice cover and sea-ice melting in the western Nordic Seas. Although less sea ice is transported out of the Arctic Ocean $(15 \%)$, the sea-ice thickness on the northern part of the EGC is higher in 9kOG compared to 9kOGSIB (Fig. 5a), implying that more sea ice is produced there. In our simulation with a dry shelf (9kOGSIB) sea-ice production in the Arctic is reduced, but also the area of ocean covered with sea ice, with the net effect that more sea ice is available for export rather than piling up in the Arctic Ocean. Annual Arctic seaice volume increases due to shelf flooding $\left(+933 \mathrm{~km}^{3}\right)$, as a result of both an increase in annual cumulative ice production and a decrease in annual cumulative ice export through the Fram Strait (Table 2). However, it should be noted that this surplus of ice is divided over a larger area in 9kOG, since the available ocean area increases by $12 \%$ due to the shelf flooding. This shows that a dry Siberian shelf has a clear impact on sea-ice production and on the export to the Nordic Seas. However, given the fact that we find a reduction in ice export through the Fram Strait, the increase of sea-ice cover and related cooling and freshening of the ocean surface in the Nordic Seas is only indirectly caused by the flooding of the shelf rather than a direct consequence of an increase in seaice export as was suggested in the original hypothesis. Thus, an additional mechanism is required to explain the changes in the Nordic Seas. This additional mechanism is associated with an atmospheric feedback that is incorporated in the response to the flooding.

\subsection{Impact on Northern Hemisphere climate}

\subsubsection{Atmospheric changes}

The flooding of the shelf decreases the pole-to-equator temperature gradient in the winter atmosphere resulting in a weakened polar vortex and increased mid-latitude North Atlantic pressure system, amplifying zonal pressure differences across the Nordic Seas and increasing the surface winds in this area. The winter warming in the Arctic $\left(2\right.$ to $8^{\circ} \mathrm{C}$,

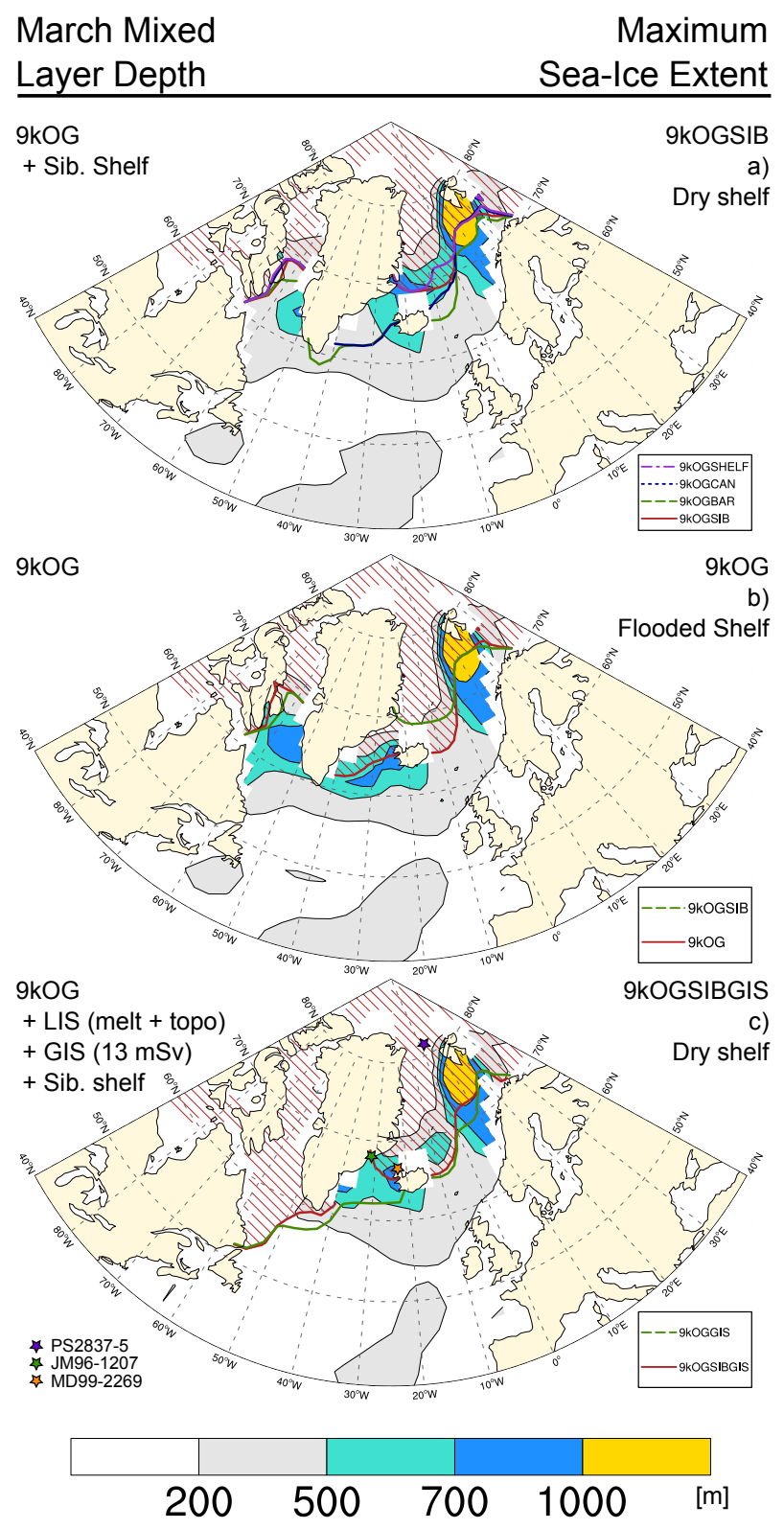

Fig. 4. Maximum winter sea-ice extent and March mixed layer depth for different simulations. (a) Simulation 9kOGSIB, and sea-ice extent contours for additional simulations 9kOGSHELF (purple), 9kOGBAR (green) and 9kOGCAN (blue). (b) simulation $9 \mathrm{kOG}$ and contours for simulation 9kOGSIB. (c) Simulation 9kOGSIBGIS and sea-ice extent contour for simulation 9kOGGIS (Blaschek and Renssen, 2013).

Fig. 6a) by the shelf flooding in $9 \mathrm{kOG}$ as compared to 9kOGSIB is directly related to changes in the land-sea mask. In summer, a cooling of 2 to $8^{\circ} \mathrm{C}$ is noted over Siberia (Fig. 6b). On an annual basis the flooding results in a cooling only over the Nordic Seas (up to $-4^{\circ} \mathrm{C}$ ) as contrasting seasonal changes (Fig. 6 a, b) balance each other out over the Siberian shelf. In summer the cooling in Siberia influences 


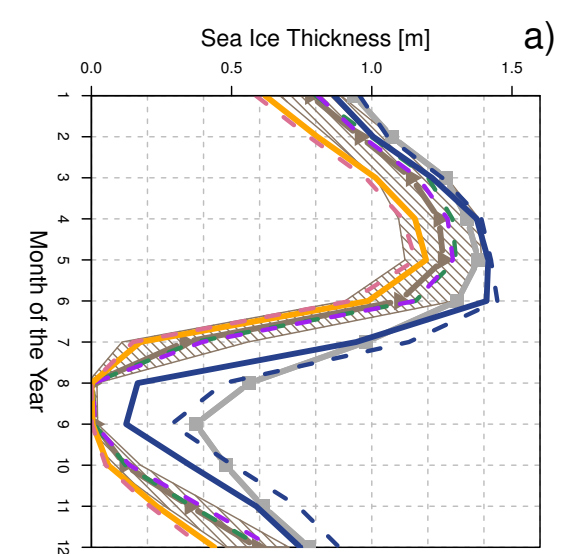

a) $\quad \begin{array}{lcl}32 & \text { SSS [p.s.u.] } \\ 32 & 34\end{array}$
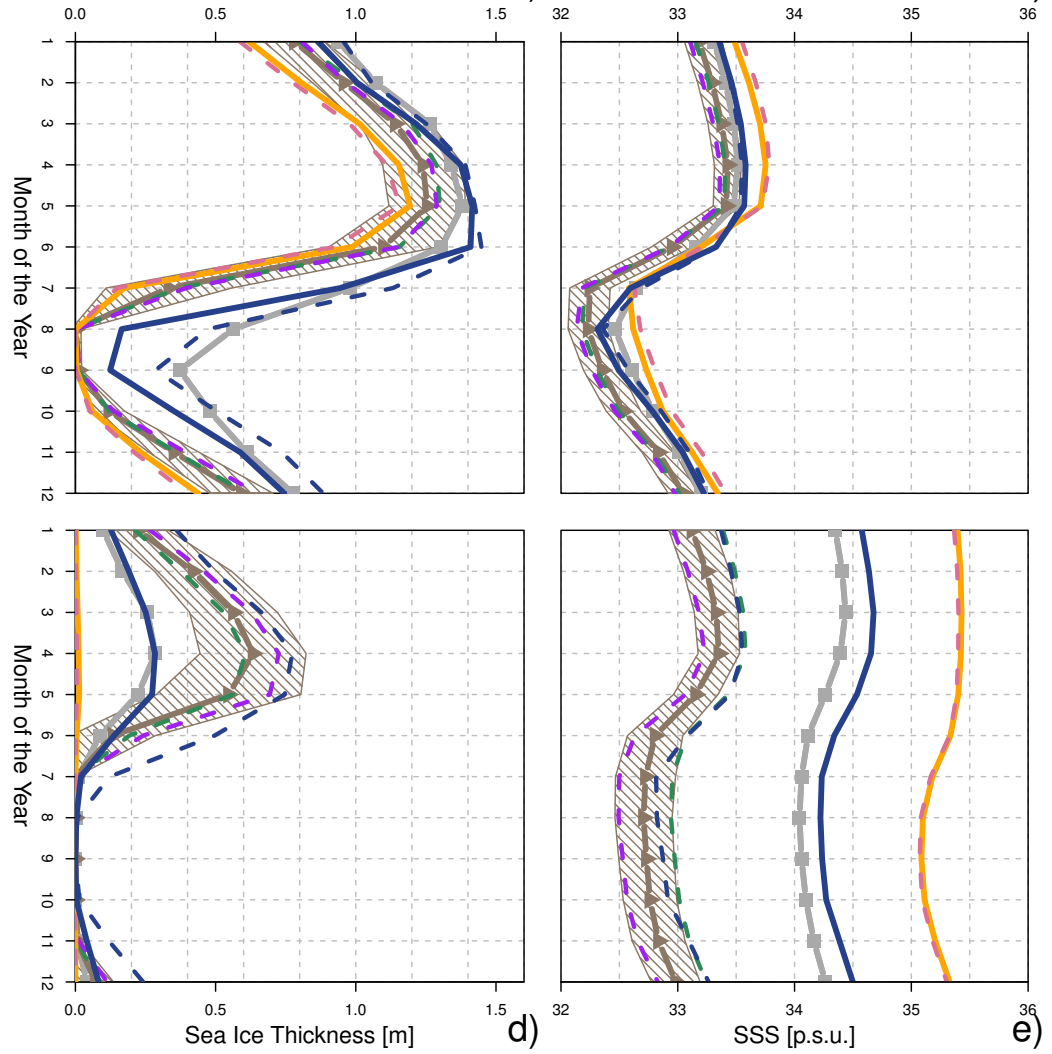

b)

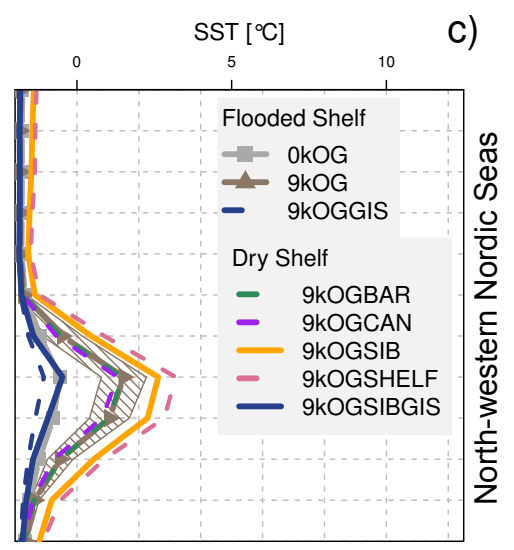

c)

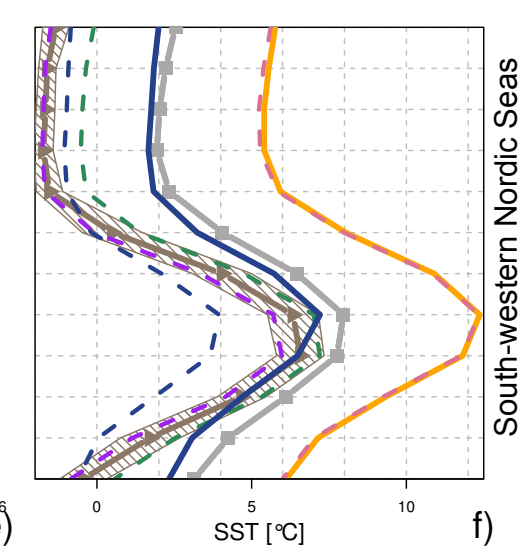

Fig. 5. Monthly means of the last $100 \mathrm{yr}$ of each simulation for the north-western Nordic Seas $\left(20-15^{\circ} \mathrm{W}, 73.75-81.25^{\circ} \mathrm{N}\right)$ in the upper panel and for the south-western Nordic Seas $\left(47.5-22.5^{\circ} \mathrm{W}, 68.75-71.25^{\circ} \mathrm{N}\right)$ as denoted in Fig. 1 blue boxes. (a/d) sea-ice thickness in metres, (b/e) sea surface salinities (SSS) in p.s.u., (c/f) sea surface temperatures in degree Celsius. Shaded areas give an estimation of the standard deviation of the monthly means for simulation $9 \mathrm{kOG}$.

a strong summer Siberian low pressure system, but results in hardly any feedback on sea ice. In winter the flooded shelf is only relatively warmer, as it is still far below zero there, but the meridional temperature gradient is somewhat reduced (by $-1.4^{\circ} \mathrm{C}$ ). The polar vortex is strongest in winter when the pole-to-equator temperature gradient is strongest. A weakening of the polar vortex and a strengthening of a mid-latitude North Atlantic high (Fig. 7a), increase the zonal pressure difference across the Nordic Seas by strengthening both the Greenland high and the Icelandic low (Fig. 7b). As a result, the associated surface winds are also strengthened, both the southward winds in the western part of the Nordic Seas and the northward winds in the eastern part (Fig. 7c). Despite the substantial difference in mean climate between 9kOG and 9kOGGIS ( $-0.5 \mathrm{~K}$ globally cooler) the impact of the shelf flooding remains clearly present as an atmospheric pattern in Fig. 7, indicating that the impact is robust. The previously mentioned bias in the Arctic atmospheric circulation in our model is affecting the transport of sea-ice in the Arctic due to changed winds, whereas one can argue that the meridional thermodynamic structure of the atmosphere is likely to be less affected by this bias, because the polar atmospheric circulation is mainly governed by its meridional component.

\subsubsection{Arctic sea-ice transport}

The flooding of the Siberian shelf alters the sea-ice transport in the Arctic (compare 9kOG with 9kOGSIB, Fig. 8) in a way that more sea ice is transported away from the production centres on the western side towards the eastern Arctic (Fig. 8) and leading to reduced export through the Fram Strait (Fig. 3). These changes in Arctic sea-ice transport are mainly associated with the new sea-ice production area over the flooded shelf. Lower export rates at the Fram Strait are mainly caused by redirection of sea ice towards the eastern side of the Arctic (Fig. 8). The impact of the shelf flooding on the ice export can be seen in the ratio of Fram Strait sea-ice export and Arctic sea-ice production, which is a measure of the Arctic sea-ice balance (e.g. for simulation OkOG this ratio is $95 \%$, meaning that $95 \%$ of the volume that has been produced until spring was also exported). This ratio decreases by $17 \%$ for simulation $9 \mathrm{kOG}(46 \%)$ as compared to 9kOGSIB (63\%) and by $11 \%$ for 9kOGGIS $(50 \%)$ 


\section{Seasonal Surface Air Temperatures}

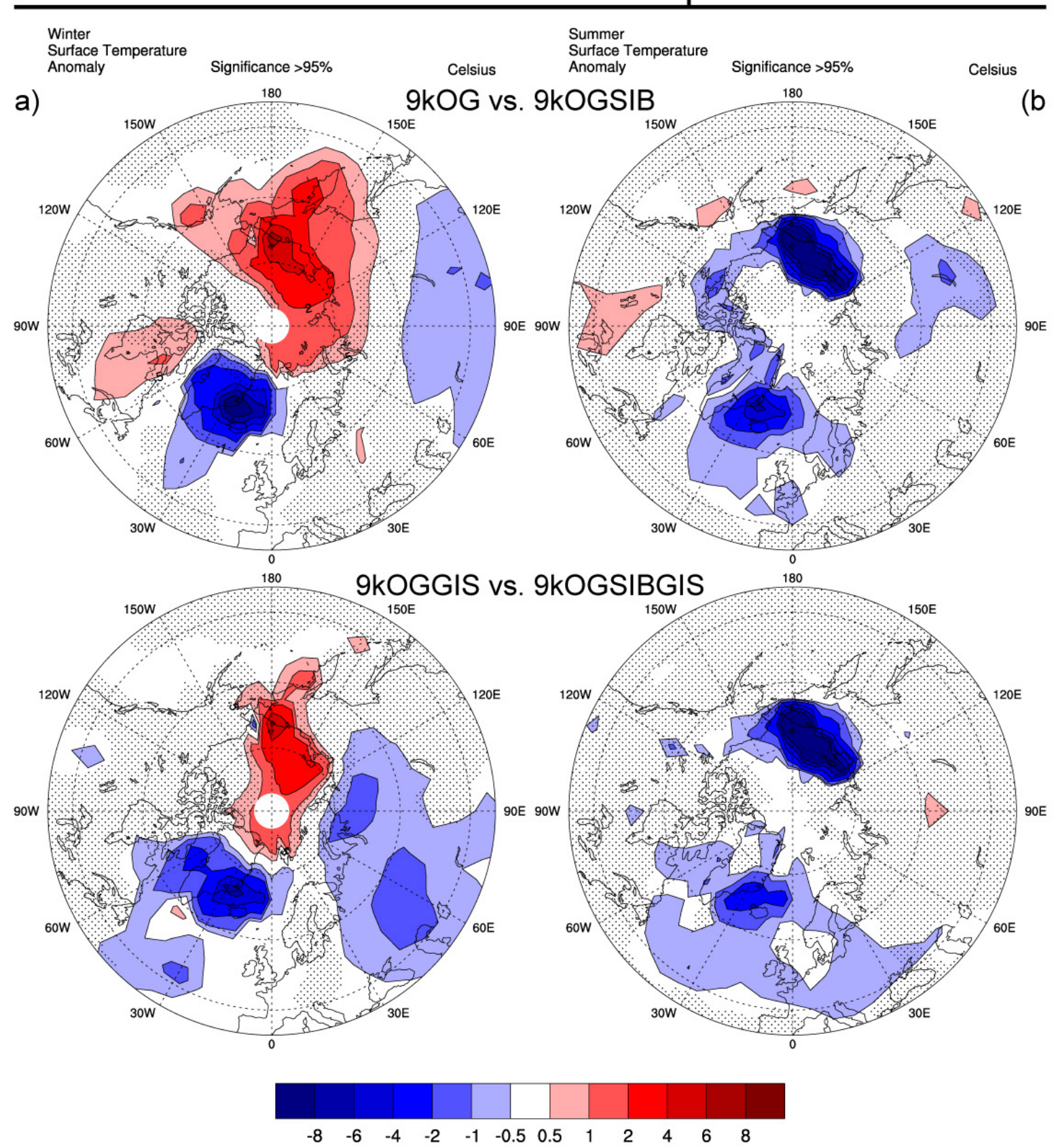

Fig. 6. Seasonal surface temperature anomalies of simulation 9kOG as compared to 9kOGSIB (upper panel) and simulation 9kOGGIS as compared to 9kOGSIBGIS (lower panel). Winter is DJF (a), Summer is JJA (b). Shaded area denotes insignificant changes compared to 9kOGSIB or 9kOGSIBGIS according to a Student $t$ test.

as compared to 9kOGSIBGIS (61\%). The response to the flooding of the Barents or the CAA shelf do not show such decreases. An increase of Arctic sea-ice production and a decrease of Fram Strait export represents a unique combination of cause and effect in our model that is connected to the flooding of Siberian shelf. In the northern EGC, higher val- ues of sea-ice thickness are related to a local increase in seaice production that is mainly caused by increased southward winds (see Sect. 3.3.1) bringing cold polar air to the area. Subsequently, this locally produced ice is then transported further South to regions close to the Denmark Strait. 
Flooding Sib. Shelf (complete set of forcings)

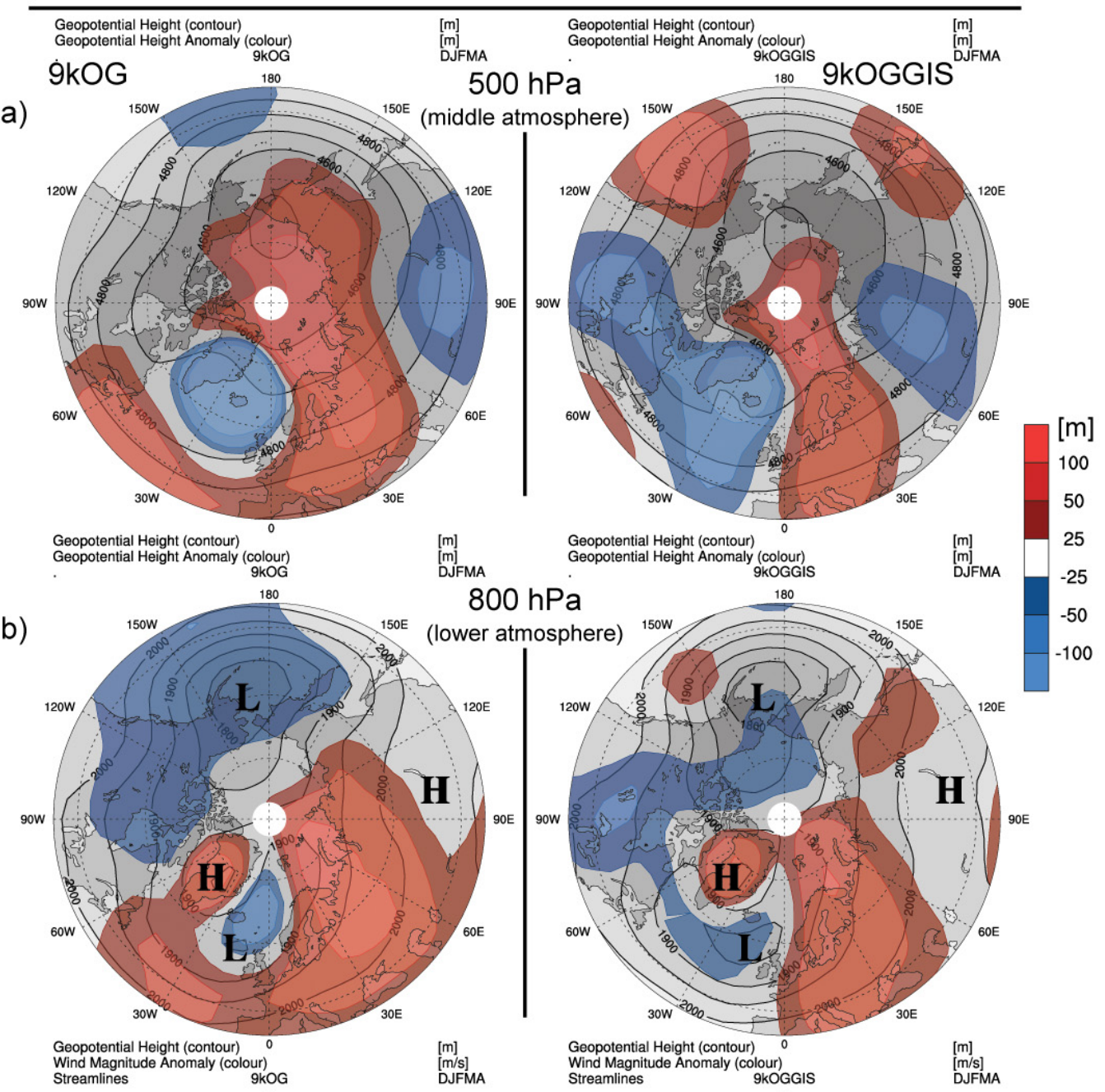

c)

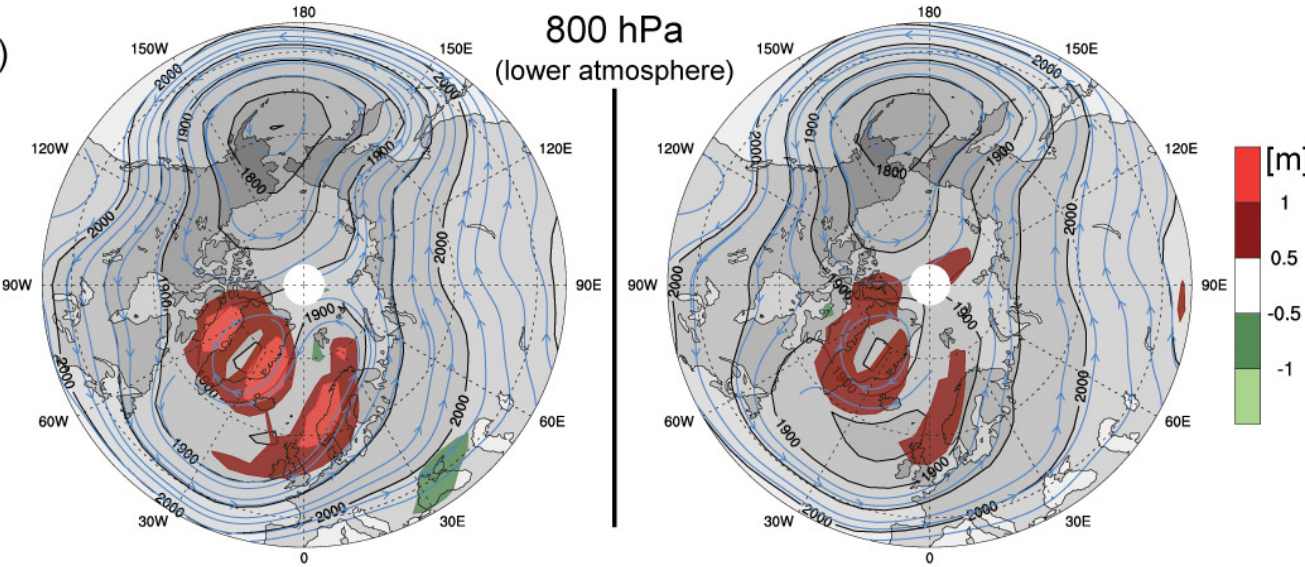

Fig. 7. Atmospheric circulation shown as heights of the $500 \mathrm{hPa}$ and $800 \mathrm{hPa}$ level. Left column represents results from simulation $9 \mathrm{kOG}$ and anomalies to 9kOGSIB, indicating the impact of shelf flooding. Right column shows results from simulation 9kOGGIS and anomalies to 9kOGSIBGIS, indicating again the impact of shelf flooding but with a complete set of forcings (LIS topography and melt water and GIS melt water). (a) upper panel shows middle atmosphere, $500 \mathrm{hPa}$ geopotential heights (gray filled contours) and anomalies (coloured contours) of geopotential height. (b) middle panel shows lower atmosphere, $800 \mathrm{hPa}$ geopotential heights (gray filled contours) and anomalies (coloured contours) of geopotential height. (c) lower panel shows $800 \mathrm{hPa}$ geopotential heights (same as middle panel) and wind magnitude anomalies (coloured contour) as well as streamlines. 


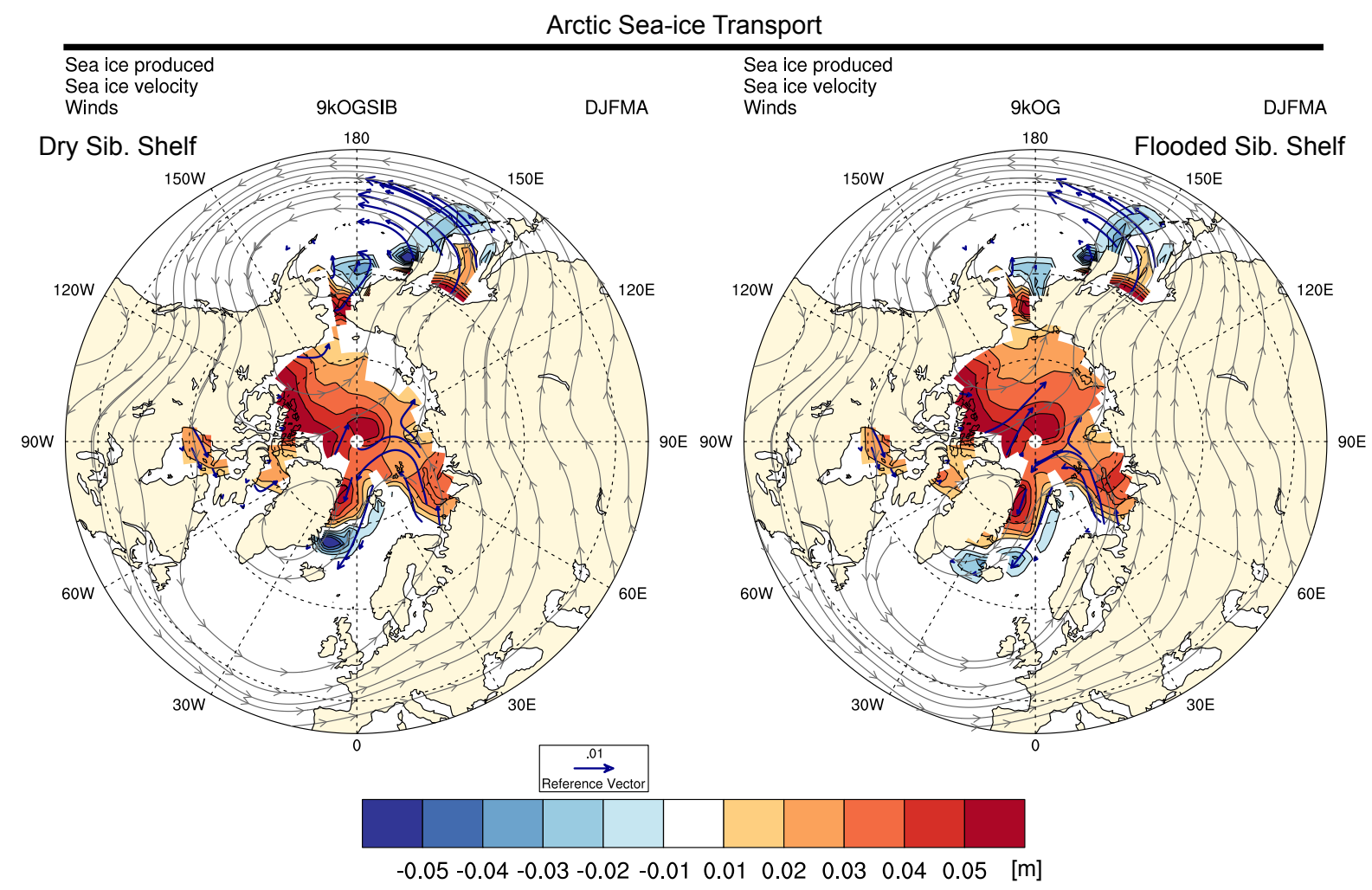

Fig. 8. Winter (December to April) cumulative sea-ice production (in m, colour shaded), sea-ice velocity (in $\mathrm{m} \mathrm{s}^{-1}$ ) as curly vectors (blue) and atmospheric winds (in $\mathrm{m} \mathrm{s}^{-1}$ ) as streamlines (grey). Left panel shows the dry Siberian shelf simulation 9kOGSIB. Right panel shows the flooded Siberian shelf simulation 9kOG.

\subsubsection{Summary}

Feedbacks from the Siberian shelf flooding as revealed in our model are illustrated in Fig. 9 and relate our findings to the bigger picture. We find a 10-step way to arrive from an orbital induced summer warming to a cooling over the Nordic Seas. The summer warming causes Northern Hemisphere ice sheets to melt (1) and raise global sea level (2). This results in flooding of the Arctic shelves (3) and thus changes land into ocean (4), which impacts both ocean and atmosphere. In the Arctic Ocean, sea-ice production is increased and Arctic seaice transport is changed resulting in decreased Fram Strait export. This reduced export was not expected in our original hypothesis (as indicated in red in Fig. 9), implying that the direct impact of the shelf flooding on the Nordic Seas through sea-ice export is not present in our simulations. However, it should be noted that our model has a low spatial resolution potentially leading to a biased atmospheric circulation over the Arctic (Goosse et al., 2003; Goosse and Renssen, 2001). In the atmosphere, the polar vortex is weakened (5) and increased pressure difference across the Nordic Seas yield stronger winds bringing relatively cold air to the area that increase the Nordic Seas sea-ice production and transport of sea ice along the EGC (6). As a result, the sea-ice margin expands further south (7), resulting in a southward shift of deep convection (8) in the western Nordic Seas. Convection and sea-ice margin are closely bound to each other and migrate north and south together. Nonetheless these changes to convection in the western Nordic Seas reduces the Atlantic meridional overturning strength (9) at $27^{\circ} \mathrm{N}$ by $4 \%$ (Table 2) and the Atlantic oceanic heat transport at the equator by $7 \%$ (not shown), but produce no significant change in atmospheric heat transport (not shown). This chain of processes due to a flooding of the Siberian shelf is also active in our simulations including LIS and GIS background forcings and give a $11 \%$ reduction of the overturning strength and a $12 \%$ decrease of Atlantic oceanic heat transport. Finally, the flooding leads to a significant annual cooling over the Nordic Seas connected to sea-ice expansion south along the EGC (Fig. 4) as opposed to an orbitally induced warming that is usually associated with the early Holocene.

\section{Discussion}

An important result from our early Holocene simulations is that the impact of the flooding of the Siberian shelf on the Arctic sea-ice production cycle remains even with major forcings as the LIS and the GIS being included in 9kOGGIS as compared to 9kOGSIBGIS. Given that the flooding of the 


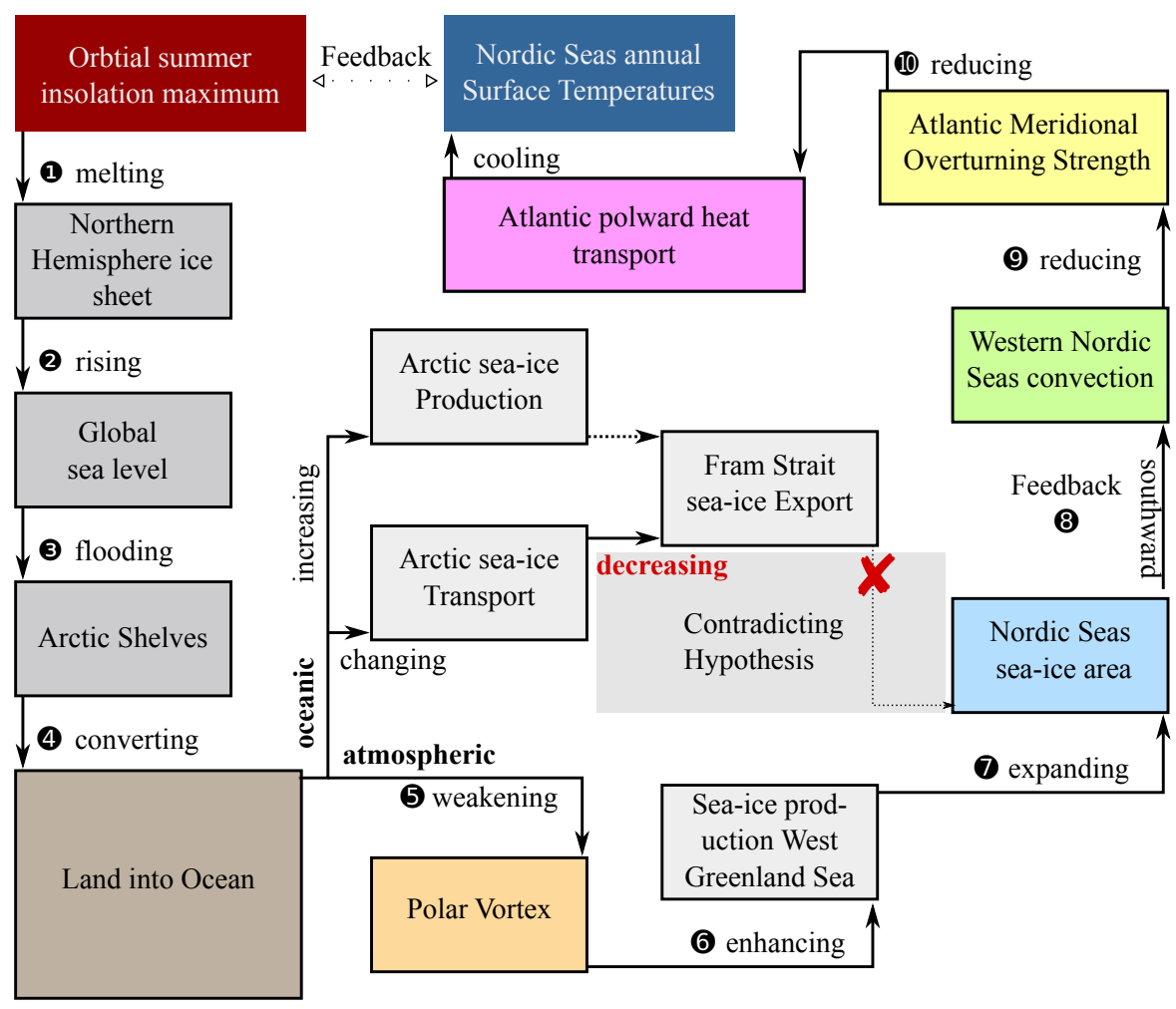

Fig. 9. Schematic 10 step way showing the connections between found feedbacks due to Arctic shelf flooding. In red is indicated where our results do not match our original hypothesis (we proposed increased Fram Strait sea-ice export and therefore an increase of Nordic Seas sea-ice area).

Siberian shelf proved to have important effects on the climate in the Arctic, and in particular in the Nordic Seas, we want to compare our results in the following section with proxy estimates of sea-ice conditions and try to relate our found feedbacks of the Siberian shelf flooding to the reconstructed transgression of Bauch et al. (2001) and Taldenkova et al. (2010), which gives our simulated impacts a time frame from $9 \mathrm{ka}$, a dry shelf as in 9kOGSIB / 9kOGSIBGIS, to $7.5 \mathrm{ka} \mathrm{BP}$, a flooded shelf as in 9kOG / 9kOGGIS.

The early Holocene is a period that is still strongly influenced by deglaciation, with pronounced melting of the Laurentide and Greenland ice sheets, resulting in relatively cold conditions in large parts of the Northern Hemisphere (Blaschek and Renssen, 2013; Renssen et al., 2009) and a rise in sea level across the globe. As these impacts begin to fade out, the orbitally induced changes in summer insolation become the main driver of Northern Hemisphere climate, leading first to a thermal maximum, followed by a long-term cooling. Connected to our results a direct impact can be seen in the Nordic Seas sea-ice extent which can be inferred by sea-ice proxies near the Denmark Strait. Andrews et al. (2009) present a drift ice record from North Iceland (Figs. 1, 4, orange star) showing a decrease from 12 to $10 \mathrm{ka} \mathrm{BP}$, followed by an increase with a maximum around $8.2 \mathrm{kaBP}$, a slight reduction thereafter and a continuous in- crease from $6 \mathrm{kaBP}$ until pre-industrial. The increase between 10 and $7 \mathrm{ka} \mathrm{BP}$ seems odd, as this period is also known as the Holocene Thermal Maximum (HTM) and reduced drift ice would be expected. Following the reconstructions by Bauch et al. (2001), the Siberian shelf must have been dry before $7 \mathrm{ka}$ BP, followed by flooding. From our simulations with a dry Siberian shelf (9kOGSIB, 9kOGSIBGIS) the seaice expansion should have been relatively small until $7 \mathrm{ka} B P$, followed by an increase, assuming that this was related to the shelf flooding. As reconstructed drift ice values by Andrews et al. (2009) between 10 and $7 \mathrm{ka}$ cannot be explained by orbital forcing or Siberian shelf flooding, another mechanism should be responsible, and it seems likely that the early Holocene LIS and the GIS have played a role. This is consistent with Blaschek and Renssen (2013), who have investigated the impact of both ice sheets on the early Holocene climate and found an advance of the sea-ice margin southward past the Denmark Strait, as can be seen in our simulation 9kOGGIS (Fig. 4c) as well. Another record from the Nansen Trough (Figs. 1, 4, green star) from Jennings et al. (2002) shows an increase in ice-rafted debris (IRD) from around $5 \mathrm{ka}$ BP after relatively low values for the early Holocene. This low IRD content indicates either that ice margins must have retreated or that the icebergs melted in the fjords (Jennings et al., 2002). In simulation $9 \mathrm{kOG}$ the sea-ice margin reaches 
beyond the Nansen Fjord and including LIS and GIS into the simulations (9kOGGIS) increases the likelihood of a sea-ice margin in that region (Fig. 4c). Thus including a dry Siberian shelf in simulation 9kOGSIBGIS (Fig. 4c) forces the seaice margin in that particular area to retreat and could potentially explain these lower IRD reconstructions in the early Holocene.

Another way of retrieving information on past sea-ice conditions are biomarkers produced by sea-ice diatoms, such as IP25 (isoprenoid lipid) and sterol brassicasterol derived from phytoplankton (Müller et al., 2009). In combination with brassicasterol, IP25 can be used to estimate sea-ice cover for spring and its seasonal behaviour. Müller et al. (2009) used these proxies to reconstruct sea-ice conditions at the Fram Strait over the last 30 ka (Figs. 1, 4, purple star). They find that IP25 was higher from 11.5 to $8.4 \mathrm{kaBP}$ and strong fluctuations in the IP25 flux occurred from 8.4 to $8.2 \mathrm{kaBP}$, followed by a period of relatively low IP25 from 8 to $5 \mathrm{ka} \mathrm{BP}$. Higher IP25 values indicate less persistent seaice cover in spring, while lower values refer to more persistent sea-ice cover in spring. Although it is difficult to find a model variable that is comparable to these reconstructed values, we find an increase in the seasonal sea-ice cover over the north-western Nordic Seas (Fig. 5a) in response to the Siberian shelf flooding in simulation 9kOGGIS as compared to $9 \mathrm{kOGSIBGIS.} \mathrm{This} \mathrm{equilibrium} \mathrm{response} \mathrm{of} \mathrm{sea-ice} \mathrm{cover}$ near the Fram Strait and the northern EGC can be seen as a temporal evolution of sea-ice cover from 9 to $7.5 \mathrm{ka} \mathrm{BP}$ from reduced (9kOGSIBGIS) to increased sea-ice cover after the flooding (9kOGGIS). The flooding of the Siberian shelf from 9 to $7.5 \mathrm{ka}$ BP increased the sea-ice cover at the Fram Strait, especially during summer. From our early Holocene simulations, we can see that the Northern Hemisphere becomes almost sea-ice free (Figs. 2, 5a, d), allowing insolation to warm surface waters, thus delaying the subsequent winter cooling and sea-ice production. This is also important because it means that in the early Holocene Arctic sea-ice cover had to build up each winter and that in comparison to present day the Arctic Ocean was not a reservoir for sea ice, which could then affect reconstructed sea-ice quantities. Nevertheless one has to keep in mind that LOVECLIM underestimates present-day sea-ice volume and that early Holocene sea-ice loss is likely to be less severe.

Additional reconstructions of past sea-ice conditions would be required to shed more light on the sequence of events in the early Holocene and in particular on the impact of shelf flooding. This relates also to times of rising sea levels during terminations, when Arctic shelves became flooded and cooled Nordic Seas surface temperatures, possibly impacting moisture transport to adjacent ice sheets and altering Northern Hemisphere climate response to orbital-induced insolation maxima. The opposite response could be proposed during times of relatively low sea levels when a warming of the Nordic Seas could increase moisture transport to adjacent ice sheets.

\section{Conclusions}

In this paper we tested the following hypothesis in simulations with early Holocene forcings, performed with the LOVECLIM model: the flooding of Arctic shelves results in a major increase in sea-ice production, leading to enhanced sea-ice volume and export through the Fram Strait. Following this hypothesis, we expected to find in the early Holocene (before the flooding at $8.9 \mathrm{ka} \mathrm{BP}$ ) a reduction of sea-ice production and lower sea-ice cover along the EGC together with increased SSTs and SSSs. Our model results indicate the following:

- There is $15 \%\left(3100 \mathrm{~km}^{3}\right)$ more sea-ice produced in a simulation with flooded Siberian shelf (9kOG) relative to an experiment with a dry Siberian shelf (9kOGSIB), accompanied by an increase of $12 \%\left(943 \mathrm{~km}^{3}\right)$ in Northern Hemisphere mean sea-ice volume and $14 \%$ $\left(1.08 \times 10^{12} \mathrm{~km}^{2}\right)$ area.

- In contrast to the hypothesis, sea-ice export through the Fram Strait is reduced by $15 \%\left(1138 \mathrm{~km}^{3}\right.$, annual sum) in a simulation with a flooded shelf ( $9 \mathrm{kOG}) \mathrm{com}-$ pared to an experiment with a dry shelf (9kOGSIB). This annual decrease is statistically significant and originates from changes in the Arctic sea-ice transport.

- The reduction of high latitude land surface area in a simulation with a flooded shelf reduces the seasonal temperature contrast by $2-10{ }^{\circ} \mathrm{C}$ at the shelf and reduces the winter pole-to-equator temperature gradient by $1.4^{\circ} \mathrm{C}$.

- A weakening of the polar vortex due to the noted weaker meridional temperature gradient, results in a strengthening of the Greenland winter high and Icelandic winter low. Increased zonal pressure differences in the Nordic Seas yield stronger southward winds along the EGC, bringing relatively cold air, and stronger northward winds along the Norwegian Atlantic Current.

- Stronger, relatively cold, southward winds along the EGC enhance local sea-ice production and push the sea-ice extent in the Nordic Seas further south, thereby shifting convective activity, to a site closer to the new ice edge near the Denmark Strait $\left(63^{\circ} \mathrm{N}\right)$, and reducing local SSTs and SSSs along the EGC.

- In a simulation with only a flooded shelf, the Nordic Seas region is cooled up to $-4{ }^{\circ} \mathrm{C}$. In a simulation with a more complete set of forcings (i.e. also including Laurentide ice sheet topography and melt water and Greenland ice sheet melt water) in the early Holocene, the flooding of the shelf results in a similar cooling.

We find that our hypothesis can be mostly confirmed from our model sensitivity study, despite the unforeseen decrease 
of Fram Strait sea-ice export. The atmosphere-ocean interaction shows clearly that changes in land-sea distribution are able to force changes in sea-ice production and affect sea surface conditions in the Nordic Seas, which is the major pathway of Arctic sea-ice export. Changes in Nordic Seas seaice extent affect local convection and alter ocean-atmosphere heat exchange, modifying seasonal atmospheric circulation. This finding underlines the importance of the Nordic Seas for the global climate and its influences originating from Arctic shores. It is likely that during previous terminations of glacial periods, a rising sea level must have also triggered Arctic shelf flooding events, temporarily pausing the progress of a termination by an external forcing, possibly even causing a reversal event. Therefore, global sea level and in particular regional sea level rise is of high significance for all terminations and must be considered in modelling of terminations.

Acknowledgements. This work was supported by funding of the European Community's 7th Framework Program FP7 2007/2013, Marie-Curie Actions, under grant agreement no. 238111 - CASE ITN. We further thank R. Spielhagen for directing our attention to this interesting phenomena and D. Roche for his excellent help in tackling the modelling challenges. This support is gratefully acknowledged.

Edited by: J. Giraudeau

\section{References}

Andrews, J., Darby, D., Eberle, D., Jennings, A., Moros, M., and Ogilvie, A.: A robust, multisite Holocene history of drift ice off northern Iceland: implications for North Atlantic climate, The Holocene, 19, 71-77, doi:10.1177/0959683608098953, 2009.

Bauch, H., Mueller-Lupp, T., Taldenkova, E., Spielhagen, R., Kassens, H., Grootes, P., Thiede, J., Heinemeier, J., and Petryashov, V.: Chronology of the Holocene transgression at the North Siberian margin, Global Planet. Change, 31, 125-139, doi:10.1016/S0921-8181(01)00116-3, 2001.

Blaschek, M. and Renssen, H.: The Holocene thermal maximum in the Nordic Seas: Blaschek, M. and Renssen, H.: The Holocene thermal maximum in the Nordic Seas: the impact of Greenland Ice Sheet melt and other forcings in a coupled atmosphere-sea ice-ocean model, Clim. Past, 9, 1629-1643, doi:10.5194/cp-91629-2013, 2013.

Brovkin, V., Bendtsen, J., Claussen, M., Ganopolski, A., Kubatzki, C., Petoukhov, V., and Andreev, A.: Carbon cycle, vegetation, and climate dynamics in the Holocene: Experiments with the CLIMBER-2 model, Global Biogeochem. Cy., 16, 86-1-86-20, doi:10.1029/2001GB001662, 2002.

Carlson, A. E. and Clark, P. U.: Ice sheet sources of sea level rise and freshwater discharge during the last deglaciation, Rev. Geophys., 50, doi:10.1029/2011RG000371, 2012.

Dethleff, D. and Kuhlmann, G.: Fram Strait sea-ice sediment provinces based on silt and clay compositions identify Siberian Kara and Laptev seas as main source regions, Polar Res., 29, 265-282, doi:10.1111/j.1751-8369.2010.00149.x, 2010.
Dethleff, D., Loewe, P., and Kleine, E.: The Laptev Sea flaw lead-detailed investigation on ice formation and export during 1991/1992 winter season, Cold Reg. Sci. Technol., 27, 225-243, doi:10.1016/S0165-232X(98)00005-6, 1998.

Dmitrenko, I. A., Kirillov, S. A., Tremblay, L. B., Bauch, D., and Willmes, S.: Sea-ice production over the Laptev Sea shelf inferred from historical summer-to-winter hydrographic observations of 1960s-1990s, Geophys. Res. Lett., 36, L13605, doi:10.1029/2009GL038775, 2009.

Elias, S. A., Short, S. K., Nelson, C. H., and Birks, H. H.: Life and times of the Bering land bridge, Nature, 382, 60-63, doi:10.1038/382060a0, 1996.

Fichefet, T. and Maqueda, M. A. M.: Sensitivity of a global sea ice model to the treatment of ice thermodynamics and dynamics, J. Geophys. Res., 102, 12609-12646, doi:10.1029/97JC00480, 1997.

Fichefet, T. and Maqueda, M. A. M.: Modelling the influence of snow accumulation and snow-ice formation on the seasonal cycle of the Antarctic sea-ice cover, Clim. Dynam., 15, 251-268, doi:10.1007/s003820050280, 1999.

Friedrich, T., Timmermann, A., Menviel, L., Elison Timm, O., Mouchet, A., and Roche, D. M.: The mechanism behind internally generated centennial-to-millennial scale climate variability in an earth system model of intermediate complexity, Geosci. Model Dev., 3, 377-389, doi:10.5194/gmd-3-377-2010, 2010.

Goosse, H. and Fichefet, T.: Importance of ice-ocean interactions for the global ocean circulation: A model study, J. Geophys. Res., 104, 23337-23355, doi:10.1029/1999JC900215, 1999.

Goosse, H. and Renssen, H.: A two-phase response of the Southern Ocean to an increase in greenhouse gas concentrations, Geophys. Res. Lett., 28, 3469-3472, doi:10.1029/2001GL013525, 2001.

Goosse, H., Selten, F., Haarsma, R., and Opsteegh, J.: Decadal variability in high northern latitudes as simulated by an intermediate-complexity climate model, Ann. Glaciol., 33, 525532, doi:10.3189/172756401781818482, 2001.

Goosse, H., Selten, F. M., Haarsma, R. J., and Opsteegh, J. D.: Large sea-ice volume anomalies simulated in a coupled climate model, Clim. Dynam., 20, 523-536, doi:10.1007/s00382-002-0290-4, 2003.

Goosse, H., Driesschaert, E., Fichefet, T., and Loutre, M.-F.: Information on the early Holocene climate constrains the summer sea ice projections for the 21 st century, Clim. Past, 3, 683-692, doi:10.5194/cp-3-683-2007, 2007.

Goosse, H., Brovkin, V., Fichefet, T., Haarsma, R., Huybrechts, P., Jongma, J., Goosse, H., Brovkin, V., Fichefet, T., Haarsma, R., Huybrechts, P., Jongma, J., Mouchet, A., Selten, F., Barriat, P.-Y., Campin, J.-M., Deleersnijder, E., Driesschaert, E., Goelzer, H., Janssens, I., Loutre, M.-F., Morales Maqueda, M. A., Opsteegh, T., Mathieu, P.-P., Munhoven, G., Pettersson, E. J., Renssen, H., Roche, D. M., Schaeffer, M., Tartinville, B., Timmermann, A., and Weber, S. L.: Description of the Earth system model of intermediate complexity LOVECLIM version 1.2, Geosci. Model Dev., 3, 603-633, doi:10.5194/gmd-3-603-2010, 2010.

Jennings, A. E., Knudsen, K. L., Hald, M., Hansen, C. V., and Andrews, J. T.: A mid-Holocene shift in Arctic sea-ice variability on the East Greenland Shelf, The Holocene, 12, 49-58, doi:10.1191/0959683602hl519rp, 2002.

Kanzow, T., Cunningham, S. A., Johns, W. E., Hirschi, J. J.M., Marotzke, J., Baringer, M. O., Meinen, C. S., Chidichimo, 
M. P., Atkinson, C., Beal, L. M., Bryden, H. L., and Collins, J.: Seasonal Variability of the Atlantic Meridional Overturning Circulation at $26.5^{\circ} \mathrm{N}$, J. Clim., 23, 5678-5698, doi:10.1175/2010JCLI3389.1, 2010.

Kwok, R., Cunningham, G. F., and Pang, S. S.: Fram Strait sea ice outflow, J. Geophys. Res.-Oceans, 109, C01009, doi:10.1029/2003JC001785, 2004.

Lambeck, K. and Chappell, J.: Sea Level Change Through the Last Glacial Cycle, Science, 292, 679-686, doi:10.1126/science.1059549, 2001.

Meinshausen, M., Smith, S., Calvin, K., Daniel, J., Kainuma, M., Lamarque, J.-F., Matsumoto, K., Montzka, S., Raper, S., Riahi, K., Thomson, A., Velders, G., and van Vuuren, D.: The RCP greenhouse gas concentrations and their extensions from 1765 to 2300, Climatic Change, 109, 213-241, doi:10.1007/s10584011-0156-z, 2011.

Müller, J., Masse, G., Stein, R., and Belt, S. T.: Variability of seaice conditions in the Fram Strait over the past 30000 years, Nat. Geosci., 2, 772-776, doi:10.1038/ngeo665, 2009.

National Geophysical Data Center, NESDIS, N. U. D. o. C.: NGDC, ETOPO2 Global 2' Elevations, http://rda.ucar.edu/ datasets/ds759.3, 2001.

Opsteegh, J. D., Haarsma, R. J., Selten, F. M., and Kattenberg, A.: ECBILT: a dynamic alternative to mixed boundary conditions in ocean models, Tellus A, 50, 348-367, doi:10.1034/j.16000870.1998.t01-1-00007.x, 1998.

Peltier, W.: Global Glacial Isostasy And The Surface Of The Ice-age Earth: The ICE-5G (VM2) Model And Grace, Annu. Rev. Earth Pl. Sc., 32, 111-149, doi:10.1146/annurev.earth.32.082503.144359, 2004.

Polyak, L., Alley, R. B., Andrews, J. T., Brigham-Grette, J., Cronin, T. M., Darby, D. A., Dyke, A. S., Fitzpatrick, J. J., Funder, S., Holland, M., Jennings, A. E., Miller, G. H., O'Regan, M., Savelle, J., Serreze, M., St. John, K., White, J. W., and Wolff, E.: History of sea ice in the Arctic, Quataternary Sci. Rev., 29, 1757-1778, doi:10.1016/j.quascirev.2010.02.010, 2010.

Rayner, N. A., Parker, D. E., Horton, E. B., Folland, C. K., Alexander, L. V., Rowell, D. P., Kent, E. C., and Kaplan, A.: Global analyses of sea surface temperature, sea ice, and night marine air temperature since the late nineteenth century, J. Geophy. Res.Atmos., 108, 4407, doi:10.1029/2002JD002670, 2003.

Renssen, H., Seppa, H., Heiri, O., Roche, D. M., Goosse, H., and Fichefet, T.: The spatial and temporal complexity of the Holocene thermal maximum, Nature Geosci., 2, 411-414, doi:10.1038/ngeo513, 2009.

Renssen, H., Goosse, H., Crosta, X., and Roche, D. M.: Early Holocene Laurentide Ice Sheet deglaciation causes cooling in the high-latitude Southern Hemisphere through oceanic teleconnection, Paleoceanography, 25, PA3204, doi:10.1029/2009PA001854, 2010.

Renssen, H., Seppä, H., Crosta, X., Goosse, H., and Roche, D.: Global characterization of the Holocene Thermal Maximum, Quaternary Sci. Rev., 48, 7-19, doi:10.1016/j.quascirev.2012.05.022, 2012.

Rigor, I. and Colony, R.: Sea-ice production and transport of pollutants in the Laptev Sea, 1979-1993, Sci. Total Environ., 202, 89-110, doi:10.1016/S0048-9697(97)00107-1, 1997.

Roche, D. M., Dokken, T. M., Goosse, H., Renssen, H., and Weber, S. L.: Climate of the Last Glacial Maximum: sensitivity studies and model-data comparison with the LOVECLIM coupled model, Clim. Past, 3, 205-224, doi:10.5194/cp-3-205-2007, 2007.

Roche, D. M., Renssen, H., and Paillard, D.: A Spatial View on Temperature Change and Variability During the Last Deglaciation: A Model Analysis, in: Climate Change, edited by: Berger, A., Mesinger, F., and Sijacki, D., 79-91, Springer Vienna, doi:10.1007/978-3-7091-0973-1_6, 2012.

Siddall, M., Rohling, E. J., Almogi-Labin, A., Hemleben, C., Meischner, D., Schmelzer, I., and Smeed, D. A.: Sea-level fluctuations during the last glacial cycle, Nature, 423, 853-858, doi:10.1038/nature01690, 2003.

Singarayer, J. S. and Valdes, P. J.: High-latitude climate sensitivity to ice-sheet forcing over the last $120 \mathrm{kyr}$, Quaternary Sci. Rev., 29, 43-55, doi:10.1016/j.quascirev.2009.10.011, 2010.

Spreen, G., Kern, S., Stammer, D., and Hansen, E.: Fram Strait sea ice volume export estimated between 2003 and 2008 from satellite data, Geophys. Res. Lett., 36, L19502, doi:10.1029/2009GL039591, 2009.

Svendsen, J. I., Alexanderson, H., Astakhov, V. I., Demidov, I., Dowdeswell, J. A., Funder, S., Gataullin, V., Henriksen, M., Hjort, C., Houmark-Nielsen, M., Hubberten, H. W., Ingólfsson, O., Jakobsson, M., Kjær, K. H., Larsen, E., Lokrantz, H., Lunkka, J. P., Lyså, A., Mangerud, J., Matiouchkov, A., Murray, A., Möller, P., Niessen, F., Nikolskaya, O., Polyak, L., Saarnisto, M., Siegert, C., Siegert, M. J., Spielhagen, R. F., and Stein, R.: Late Quaternary ice sheet history of northern Eurasia, Quaternary Sci. Rev., 23, 1229-1271, doi:10.1016/j.quascirev.2003.12.008, 2004.

Taldenkova, E., Bauch, H. A., Gottschalk, J., Nikolaev, S., Rostovtseva, Y., Pogodina, I., Ovsepyan, Y., and Kandiano, E.: History of ice-rafting and water mass evolution at the northern Siberian continental margin (Laptev Sea) during Late Glacial and Holocene times, Quaternary Sci. Rev., 29, 3919-3935, doi:10.1016/j.quascirev.2010.09.013, 2010.

Tamura, T. and Ohshima, K. I.: Mapping of sea ice production in the Arctic coastal polynyas, J. Geophys. Res., 116, C07030, doi:10.1029/2010JC006586, 2011.

Weaver, A. J., Sedláǒek, J., Eby, M., Alexander, K., Crespin, E., Fichefet, T., Philippon-Berthier, G., Joos, F., Kawamiya, M., Matsumoto, K., Steinacher, M., Tachiiri, K., Tokos, K., Yoshimori, M., and Zickfeld, K.: Stability of the Atlantic meridional overturning circulation: A model intercomparison, Geophys. Res. Lett., 39, L20709, doi:10.1029/2012GL053763, 2012.

Werner, K., Spielhagen, R. F., Bauch, D., Hass, H. C., and Kandiano, E.: Atlantic Water advection versus sea-ice advances in the eastern Fram Strait during the last 9ka: Multiproxy evidence for a two-phase Holocene, Paleoceanography, 28, 283-295 doi:10.1002/palo.20028, 2013.

Wiersma, A. and Renssen, H.: Model-data comparison for the 8.2 ka BP event: confirmation of a forcing mechanism by catastrophic drainage of Laurentide Lakes, Quaternary Sci. Rev., 25, 63-88, doi:10.1016/j.quascirev.2005.07.009, 2006.

Willmes, S., Adams, S., Schröder, D., and Heinemann, G.: Spatiotemporal variability of polynya dynamics and ice production in the Laptev Sea between the winters of $1979 / 80$ and 2007/08, Polar Res., 30, 5971, doi:10.3402/polar.v30i0.5971, 2011. 
Zakharov, V.: The role of flaw leads off the edge of fast ice in the hydrological and ice regime of the Laptev Sea, Oceanology, 6, 815-821, 1966.
Zhang, J. and Rothrock, D. A.: Modeling Global Sea Ice with a Thickness and Enthalpy Distribution Model in Generalized Curvilinear Coordinates, Mon. Weather Rev., 131, 845-861, doi:10.1175/15200493(2003)131\%3C0845:MGSIWA\%3E2.0.CO;2, 2003. 